\title{
A NOVA AGENDA DE DESENVOLVIMENTO PELA ÓTICA DOS CONFLITOS SOCIAIS: 0 CASO DE BELO MONTE ${ }^{1}$
}

\section{THE NEW DEVELOPMENT AGENDA BY THE SOCIAL CONFLICTS PERSPECTIVE: THE CASE OF BELO MONTE}

\author{
Sérgio Roberto Moraes Corrêa* \\ Roberto Véras de Oliveira**
}

\section{Introdução}

Este artigo trata da emergência de uma nova agenda de desenvolvimento no Brasil, pela ótica dos conflitos sociais. Mais especif1camente, versa sobre o processo de construção do Aproveitamento Hidrelétrico de Belo Monte - AHE Belo Monte, empreendimento situado no Rio Xingu, sudoeste do Pará. Parte do pressuposto de que o ângulo dos conflitos sociais, tomados em perspectiva histórica, pode trazer importante contribuição à análise do novo momento do desenvolvimento do País e da Amazônia.

A primeira versão do projeto hidroelétrico de Belo Monte remonta à década de 1970, no contexto do Regime Militar, quando foi alcunhado de Kararaô, e com- punha um projeto mais amplo, de cinco hidrelétricas na bacia do rio Xingu. Em 1989, no processo de redemocratização do País, as manifestações de contestação a Kararaô ganharam evidência, inclusive internacional, com o I Encontro dos Povos Indígenas do Xingu, em Altamira, tendo este contribuído para a suspensão do projeto. Após sucessivas reformulações, ele chegou à sua versão atual, com o nome de Aproveitamento Hidrelétrico de Belo Monte, retomado no âmbito do Programa de Aceleração do Crescimento - PAC, do Governo Federal, marcado por fortes contradições, polêmicas e conflitos.

0 PAC se constituiu no eixo da nova agenda desenvolvimentista do Governo Federal, a partir de 2007, quando foi lançado.

\footnotetext{
* É professor da Universidade do Estado do Pará (Belém/PA/Brasil), Doutor em Ciências Sociais pela Universidade Federal de Campina Grande. sergiorcm2001@yahoo.com.br.

** É professor Associado da Universidade Federal da Paraíba (João Pessoa/PB/Brasil), vinculado ao Departamento de Ciências Sociais e ao Programa de Pós-Graduação em Sociologia. Pesquisador do CNPQ. roberto.veras.2002@gmail.com.

1. Este artigo tem como base a pesquisa de doutorado intitulada "As lutas e resistências do Movimento Xingu Vivo para Sempre diante do projeto hidrelétrico Belo Monte: o padrão de desenvolvimento da Amazônia em disputa", defendida por Sérgio Roberto Moraes Corrêa, em agosto de 2014, no PPGCS/UFCG, sob orientação de Roberto Véras de Oliveira. Agradecemos as sugestões dos pareceristas.
} 
0 Governo Lula, nesse momento, passou a dar maior realce ao papel indutor do Estado com vistas ao crescimento econômico, associando-o ao compromisso com a geração de emprego e renda e à estabilidade macroeconômica (PÊGO; CAMPOS NETO, 2008), priorizando investimentos de grande porte em infraestrutura. Até 2010, segundo dados oficiais, reunindo recursos do Governo Federal, de empresas estatais e do setor privado, foram invertidos mais de $\mathrm{R} \$ 600$ bilhões nos projetos do PAC. Dentre estes, destacaram-se os setores de energia, transporte, habitação, saneamento, recursos hídricos, além de programas de impacto social, como o "Minha Casa Minha Vida" (habitação) e o "Luz para Todos" (distribuição de energia elétrica). Com isso, a participação dos investimentos no PIB passou de 16,4\%, em 2006, para 18,4\%, em 2010 (BRASIL, 2010).

Com a eclosão da crise financeira global em 2008, o governo, para contornar os impactos que esta crise traria ao País, atribuiu uma atenção ainda maior às obras do PAC, apostando no fortalecimento do setor produtivo e do mercado interno, e no estímulo à geração de emprego e renda. 0 sucesso das ações implementadas reafirmou o discurso desenvolvimentista. Quando da posse de Dilma, com a segunda versão do Programa, foram confirmados os eixos estruturantes da sua primeira edição.

Com o PAC, o Governo Federal retomou a implementação de uma série de grandes projetos na Região Amazônica. Entre estes, sobressaíram as obras de construção das Usinas Hidrelétricas de Jirau e Santo Antonio, no Rio Madeira, em Rondônia e de Belo Monte, na Bacia do Xingu, no município de Vitória do Xingu, no Pará. Outros projetos estão previstos ainda para os rios Tapajós e Teles Pires, indicando forte ex- pansão da fronteira hidrelétrica na Região e sua associação a outras frentes econômicas, como a mineral e agropecuária.

0 projeto AHE Belo Monte foi licenciado pelo IBAMA - Instituto Brasileiro para o Meio-Ambiente, em 2010, e sua construção começou em 2011. Assentou-se sob o argumento da necessidade de ampliação da capacidade e segurança energética do País, da aposta na integração econômica da América do Sul e da opção preferencial por fontes de "energia limpa e renovável". Para seus defensores, trata-se de uma oportunidade para gerar emprego e renda, desenvolvimento para a região, qualidade de vida e redução da pobreza e da exclusão social (EPE/MME, 2007; 2011; TOLMASQUIM, 2010). Entretanto, foi fortemente criticado, tanto em sua viabilidade econômica, como principalmente por seus impactos sociais e ambientais (BERMANN, 2012; FEARNSIDE; MILLIKAN, 2012; HERNANDEZ; BERMANN, 2010; MAGALHAES; HERNANDEZ, 2009; SEVÁ FILHO, 2005, 2009;). Populações ribeirinhas, camponeses, povos indígenas, acadêmicos, religiosos, membros do Ministério Público Federal, ONGs, políticos, entre outros agentes, convencidos das grandes implicações socioambientais do projeto, passaram a se opor à sua implementação. Diversos movimentos e organizações populares vêm se mobilizando e se articulando sob variadas formas de reivindicações e protestos, tornando a Amazônia um território marcado por conflitos socioambientais. Nesse contexto, ganhou destaque o Movimento Xingu Vivo Para Sempre - MXVPS.

A retomada do projeto de uma grande hidroelétrica no Rio Xingu, no âmbito do PAC, nas proximidades de Altamira, no Pará, tendo se tornado uma das maiores expressões da nova agenda de desenvolvimento do 
País, suscitou reposicionamentos dos atores sociais nos planos local e regional. Um campo de organização popular, que vinha se constituindo desde os anos 1970, especialmente a partir das Comunidades Eclesiais de Base - CEBs, da Comissão Pastoral da Terra-CPT, dos Sindicatos de Trabalhadores Rurais - STRs, do Partido dos Trabalhadores - PT, viu-se fortemente tensionado por duas principais posições: uma que tende a aceitar parte dos argumentos a favor do projeto e/ou que aceita negociar compensações aos danos socioambientais por ele causados e outra que os recusa totalmente, focando no impedimento de sua concretização. Isso revela um "racha" nesse campo de resistência, reconfigurando a dinâmica dos conflitos sociais locais, agora marcada por fortes ambivalências Tal situação certamente concorreu para a aprovação e o licenciamento ambiental do projeto.

Com base nesse quadro, o presente artigo se propõe a analisar o processo social de implementação do projeto AHE Belo Monte, a partir da ótica das lutas e resistências populares, destacando o MXVPS. Este artigo orienta-se pelas seguintes questões: i) os movimentos populares de resistência ao projeto AHE Belo Monte, dada sua composição diversa e marcada, principalmente a partir da eleição de Lula, por fortes divergências internas, têm sido capazes de influir sobre a implementação do referido projeto?

ii) estes movimentos têm conseguido pôr em pauta, no debate público, suas demandas socioambientais e, assim, ressignificar a noção de desenvolvimento?; iii) que elementos aportam ao debate atual sobre uma nova agenda de desenvolvimento no País e na Amazônia? iv) em que medida essas lutas e organizações populares têm contribuído para redimensionar o projeto AHE Belo Monte, indo além de um ponto no qual, enquanto crítica social, venham a ser assimilados pela dinâmica de acumulação tão somente como justificação? ${ }^{2}$

Este texto se baseia em pesquisa qualitativa, realizada entre 2012 e 2014 , focada nos discursos e práticas constitutivas dos conflitos socioambientais produzidos em

2. Tomamos esta noção no sentido de Boltanski e Chiapello (2009, p. 35). A dinâmica de acumulação de capital requer, para capitalistas e trabalhadores, justificações morais, visando evidenciar "as vantagens coletivas, definidas em termos de bem comum, com que ela contribui para todos": "chamamos de espírito do capitalismo a ideologia que justifica o engajamento no capitalismo” (Boltanski e Chiapello, 2009, p. 39). Entretanto, como tal processo, ao encontrar sua finalidade em si mesmo (acumulação de capital), tem a capacidade de suscitar práticas coletivas desvinculadas da esfera moral, sua justificação "supõe referência a construtos de outra ordem, da qual derivam exigências completamente diferentes daquelas impostas pela busca do lucro" (idem, p. 53). 0 espírito do capitalismo necessita, para se perpetuar, "daqueles que ele indigna, daqueles que se lhe opõem, para encontrar os pontos de apoio morais que lhe faltam" (idem, p. 61). Os autores identificam dois níveis de crítica ao capitalismo. Um, "primário", que se refere à esfera das emoções e da indignação, estando sempre pronto a brotar impulsivamente. 0 outro, "secundário", tem caráter reflexivo e argumentativo, sendo capaz de dar sustentação à luta ideológica. Como principais tipos de críticas na história do capitalismo, destacam: sua associação com o desencanto e a inautenticidade; seu caráter de opressão; sua capacidade de gerar miséria para os trabalhadores e desigualdades sociais e de inspirar oportunismo e egoísmo. Propõem, com isso, uma concepção não determinista do social. 0 capitalismo e sua dinâmica de acumulação ("processo infındável e insaciável, totalmente abstrato e dissociado da satisfação de necessidades de consumo") se fazem em um jogo dialético entre a crítica social e a justificação ideológica (“o espírito do capitalismo próprio a cada época”). 
torno da implementação do projeto AHE Belo Monte, considerando os diversos agentes ali envolvidos, mas priorizando a perspectiva dos movimentos sociais. A partir desse recorte territorial, busca estabelecer conexões com a dimensão regional, nacional e internacional, para se ter uma compreensão mais ampla e complexa da problemática tratada. Como procedimentos, além de pesquisa documental, principalmente junto às organizações populares da região, priorizou entrevistas semiestruturadas e observação direta ${ }^{3}$.

\section{0 retorno do tema do desenvolvimento: posições em disputa}

A nova agenda de desenvolvimento ganhou destaque nas duas gestões de Lula e no primeiro mandato de Dilma. Resultou daí: crescimento econômico em parte do período considerado, efeito de distribuição de renda, redução da pobreza e diminuição das desigualdades mudanças que podem ser ao mesmo tempo consideradas modestas, se o parâmetro for o imenso passivo social acumulado historicamente no País, ou contrastante, se o parâmetro for a direção das políticas econômica e social adotadas ao longo da década de 1990.

Nesse contexto, ressurgiu o debate acadêmico sobre o tema do desenvolvimento. Bresser-Pereira (2003, 2006, 2012) é um dos que inaugura a discussão, tendo se utilizado da expressão "novo desenvolvimentismo". Para ele, a "ortodoxia neoliberal" não teria logrado garantir a estabilização macroeconômica e crescimento na América Latina, com isso criando a possibilidade de uma nova política econômica na região. Mas, contrapondo-se ao "populismo da esquerda burocrática e sindical” (herdeira do nacional desenvolvimentismo), recusa o protecionismo e defende o rigor fiscal e monetário, de modo a, segundo ele, gerar uma indústria competitiva voltada à exportação. Para tanto, seriam necessários Estado e mercado fortes, políticas públicas

3. Foi realizada ampla pesquisa documental junto a arquivos das empresas envolvidas no projeto AEH Belo Monte, nas instituições oficiais, especialmente do Governo Federal, mais diretamente atuantes no projeto, como IBAMA, Ministério das Minas e Energia, Ministério do Planejamento, entre outros, assim como nas organizações populares e outras instituições sociais com inserção na região. Foram realizadas 15 entrevistas no período de março de 2012 a junho de 2013, sendo $11 \mathrm{com}$ integrantes e parceiros do MXVPS e 04 com integrantes de outros movimentos e entidades. Nesse grupo, foi entrevistada uma liderança do Movimento dos Atingidos Por Barragem-MAB, que, embora tenha estabelecido uma relação de parceria com o MXVPS, não o integra, além de apresentar diferenças e divergências de posições. Também foi entrevistada uma liderança da Fundação Viver Produzir e Preservar (FVPP), entidade que historicamente integrava o MXVPS, mas que passou a apresentar posição divergente sobre como lidar com o projeto AEH Belo Monte. No tocante ao grupo de entrevistados do MXVPS, foram ouvidas as principais lideranças e parceiros. No que se refere às atividades de observação direta, um primeiro momento de incursão em campo ocorreu em junho de 2012, quando participamos do "Encontro Xingu + 23", na Comunidade Santo Antonio, território rural de Vitoria do Xingu, próximo ao canteiro principal de obra de Belo Monte, que foi ocupado ao final desse encontro pelo MXVPS, por grupos indígenas, ribeirinhos, pescadores. Um outro momento ocorreu em junho de 2013, com uma visita à Comunidade Santo Antonio, desapropriada para a construção de Belo Monte. Nessa ocasião, acompanhamos manifestações na cidade de Altamira, em protestos contra as precárias condições de vida resultantes da obra de construção de Belo Monte e do não cumprimento das condicionantes. Além desses dois momentos, em Belém, participamos de algumas ações do MXVPS realizadas em ambiente acadêmico. 
permanentes e flexibilização das relações de trabalho. Sicsú, Paula e Michel (2007) concordam em parte com as proposições de Bresser-Pereira, entretanto realçam mais fortemente a necessidade de associar crescimento econômico e equidade social.

Boschi (2011) também reconhece a presença de um maior intervencionismo estatal na América Latina, ao mesmo tempo em que destaca a dimensão social como fator de desenvolvimento e o papel estratégico do Estado para promover a inclusão social. Por esse caminho, evidencia o lugar da política com vistas à construção de um novo compromisso desenvolvimentista. Igualmente para Pochmann (2012), ao afırmar que para avançar nessa direção a constituição de uma "nova maioria política” seria imprescindível. Grosso modo, restariam duas opções ao Brasil: destinar-se à exportação de commodities ou apostar em investimentos com alto valor agregado e conhecimento, esta última sendo condição para a superação do subdesenvolvimento.

Autores como Ridenti (2009) preferiram lançar questionamentos sobre a pertinência atual do desenvolvimentismo. Lembra que, sob uma perspectiva de esquerda, o tema sofreu no passado forte crítica, visto que se baseava em análises que não davam um claro realce às lutas de classes. Do mesmo modo, para Vianna (2012), o retorno ao desenvolvimentismo sugere um "anacronismo”, posto que o nacional-desenvolvimentismo anterior apresentava uma posição "anti-imperialista" e "emancipatória". Ao contrário disso, segundo avalia, "o que se tem hoje é uma tecnocracia animada pela aspiração de desenvolver, maximizar, robustecer o capitalismo brasileiro e inscrevê-lo de forma mais presente e vigorosa no cenário do capitalismo mundial" (VIANNA, 2012, p. 01). Trata-se de uma perspectiva centrada "nos temas da economia", em defesa de "um projeto de fortalecimento do capitalismo" no País, que estaria esvaziando o sentido da política.

Boito Júnior (2012, p. 4) entende que, mesmo com o "desenvolvimentismo" de Lula e de Dilma, o País não rompeu com o "neoliberalismo". 0 que houve, nesse período, foi um "desenvolvimentismo possível dentro do modelo capitalista neoliberal”. 0 neodesenvolvimentismo, conforme o autor, é um programa conduzido por uma frente política ampla e heterogênea (que não deve ser confundida com aliança de classes), sendo hegemonizada por uma "fração da burguesia interna”, que exige do Estado proteção do mercado interno para ela frente à força do capital financeiro transnacional, bem como incentivo para a conquista do mercado externo, o que sob tal perspectiva entra em contradição com o campo político do "neoliberalismo ortodoxo".

Fiori (2011, p. 02) sustenta que os defensores do chamado "novo desenvolvimentismo" incorrem no erro de propor "um conjunto de medidas ainda mais vagas e gelatinosas do que já havia sido a ideologia nacional-desenvolvimentista dos anos 50". Avalia que "a questão central do poder e dos interesses contraditórios das classes e das nações” é deixada de lado. Em outro momento (FIORI, 2012a e 2012b), pergunta-se: por que o "desenvolvimentismo de esquerda”, ressurgido recentemente, estreitou-se tanto no seu "horizonte utópico", tornando-se uma "ideologia tecnocrática", sem capacidade de mobilização social, não sendo também capaz de construir uma nova base teórica? Cita a "Escola Campineira": embora surgida de uma crítica ao paradigma cepalino, teria sido sufocada, mais recentemente, com a crise socialista e a onda neoliberal, tendo perdido sua ca- 
pacidade teórica e seu conteúdo político. Restaria a sensação de um "horizonte utópico” estreito, sem poder de mobilização. Carneiro (2012), identificado com a "Escola Campineira”, argumenta em resposta a Luis Fiori que, diferentemente do "desenvolvimentismo de esquerda", o "novo desenvolvimentismo" teria sido uma formulação de economistas da FGV/SP, cuja ênfase nas políticas macroeconômicas colocaria em segundo plano as políticas sociais.

Para Cepêda (2012, p. 84), o "novo-desenvolvimentismo", ao contrário do "velho", “apoia-se no processo de inclusão social, colocando redistribuição e equidade em posição prioritária”. Segundo concebe, "a via de desenvolvimento por consumo de massa, transferência de renda direta (como Bolsa Família), políticas de crédito popular e economia social são características importantes de uma acepção de economia estimulada pelo 'lado da demanda' - pela tese do mercado interno e pela inovação via multiplicação de empreendedorismo popular" (CEPÊDA, 2012, p. 85).

Para Diniz (2011), o que ocorre no Brasil estaria em consonância com a tendência mundial de revigoramento da ideia de desenvolvimento, do papel do Estado, das liberdades substantivas (SEN, 1999), da questão ambiental. Constata que, no caso brasileiro, as novas políticas de desenvolvimento têm buscado associar mercado e Estado, o econômico e o social. Por outro lado, admite que ainda não teria se constituído uma coalizão de forças, suficiente para dar sustentação a um projeto desenvolvimentista. Draibe e Riesco (2011), com a noção de Estado Latino-Americano De- senvolvimentista de Bem Estar - ELADBES, buscam realçar um esforço de articulação entre economia e politica social, destacando que o jogo está em aberto e que será decido no campo da política. Kerstenetzky (2011), igualmente atenta à relação entre desenvolvimento e equidade, não admite condicionar bem estar social à existência prévia de desenvolvimento. Defende que as políticas sociais sejam economicamente orientadas e as políticas econômicas, socialmente orientadas.

Ivo (2012, p. 206), tomando como base de sua abordagem um realce central à dimensão social do desenvolvimento, chama a atenção para a importância do tema do trabalho como "eixo fundamental da integração social":

Da minha perspectiva, considero que avaliar a relevância da agenda social do desenvolvimento hoje implica analisar um padrão decisivo do Estado na distribuição e no enfrentamento da dimensão estruturante e qualificada de inserção pelo mercado de trabalho e na proteção sustentada em direitos sociais, ou na regulação das relações não mercantis (base de que tratam as políticas sociais). Conquanto se reconheçam resultados positivos no alívio à pobreza, políticas vigorosas de proteção e integração social não se restringem a programas governamentais de transferência de renda, mas dependem das condições estruturais da distribuição, da qualidade das políticas públicas e da qualidade de inserção dos indivíduos na esfera do trabalho, eixo fundamental da integração social.

No debate, aqui brevemente situado ${ }^{4}$, as diversas posições em geral reconhecem o

4. A bibliografia se estende. Entre várias outras contribuições disponiveis sobre o tema em questão, destacamos ainda o Dicionário temático - desenvolvimento e a questão social: 81 problemáticas contemporâneas (Ivo et al., 2013). 
retorno a um papel mais central do Estado na economia. Adquire centralidade a questão da compatibilização entre desenvolvimento e equidade, ponto que demarca diferenças de perspectivas. Posicionar-se no debate sobre o desenvolvimento pela ótica dos ganhos sociais, em geral implica em dar destaque ao lugar da política entendida para além do papel do Estado.

Aqui propomos uma abordagem sociológica sobre o tema do desenvolvimento entendendo-o como construção social, segundo a qual os conflitos ganham um papel central na produção de deslocamentos e reajustamentos permanentes das dinâmicas sociais. Atores histórica e socialmente constituídos se movem sob referenciais prático-discursivos diversos, capazes de gerar associações/composições, mas também divergências/dissensões ${ }^{5}$. Priorizamos, no estudo do processo social de implementação do projeto AHE Belo Monte no contexto de retomada de uma nova agenda de desenvolvimento no país, a perspectiva das lutas e resistências populares ali ensejadas, com destaque para o MXVPS.

\section{De Kararaô a Belo Monte: projetos, polê- micas e conflitos}

Na Região Norte, os investimentos do PAC se concentraram na infraestrutura energética. É o que sobressaiu do balanço ofıcial de sua primeira edição (2007-2010):

Duas das maiores hidrelétricas do mundo estão sendo construídas hoje no Brasil: Santo Antônio e Jirau, e Belo Monte será iniciada em breve. No dia 30 de novembro, o Governo Federal inaugurou as Eclusas de Tucuruí, no Pará. Um empreendimento que estava em ritmo lento havia 30 anos e que foi retomado pelo PAC. Um marco histórico para a região Norte do País (BRASIL, 2010, p. 03).

Com o PAC II (2011-2014), a aposta no setor de energia foi reafirmada, sendo considerada indispensável "para a continuidade e sustentação do crescimento do Brasil", ao mesmo tempo em que foi reforçada a prioridade para o "potencial hídrico do País" sob o argumento de ser essa uma opção "limpa e renovável” (BRASIL, 2012, p. 72). Com isso, as novas políticas desenvolvimentistas tomaram a Amazônia como território estratégico para os seus megainvestimentos público-privados.

Vistas em conjunto, tais políticas vêm conformando um padrão de desenvolvimento passível de muitos questionamentos. Conforme Leitão (2009), esses projetos tendem a reiterar um papel subordinado da Região, nacional e internacionalmente, ao reforçar um perfil exportador de energia e de commodities, reproduzindo condições socialmente excludentes e ambientalmente predatórias. Igualmente para Souza e Filippi (2010, p. 10), na Amazônia, não obstante seu peso crescente no PIB nacional, os novos investimentos não têm revertido as desigualdades sociais e regionais. Almeida (2011, p. 27) avalia que os "direitos territoriais e étnicos" de povos e comunidades tradicionais estão na mira do agronegócio. Para Castro (2012, p. 9), “a Amazônia precisa ser lida a contrapelo dos discursos opacos que querem ver a região como verde ou ligada a potencialidades econômicas que precisam, a todo custo, chegar aos mercados".

5. 0 que nos aproxima de abordagens como Sardan (2005), para quem são categorias chave para pensar o desenvolvimento, especialmente em perspectiva local: "conflitos”, "arena” e "grupos estratégicos”. 
Nesse ambiente se inserem os projetos de exploração hidroelétrica do Rio Xingu, no qual se destaca, atualmente, o AHE Belo Monte. Situado no sudoeste do estado do Pará, na Bacia do rio Xingu, em Vitória do Xingu, esta será a terceira maior hidrelétrica do mundo (e a primeira totalmente nacional), com mais de $11.000 \mathrm{MW}$ de potência, contando com o maior investimento público do PAC. 0 início do funcionamento e geração parcial de energia está previsto para 2015 e sua motorização, para janeiro de 2019 (EPE/MME, 2011). 0 projeto, no entanto, é antigo.

Na década de 1970, sob o Regime Militar, ganhou relevância a expansão da fronteira amazônica por meio de megaprojetos, a exemplo da construção da Rodovia Transamazônica e da hidroelétrica de Tucuruí. Ao mesmo tempo, em face das agressões aos modos de vida das populações locais, que daí resultaram, emergiram movimentos sociais diversos. Segmentos da Igreja Católica, orientados pela Teologia da Libertação, com destaque para as Comunidades Eclesiais de Base - CEBs e Pastorais, passaram a desempenhar importante papel na mobilização e organização desses movimentos, em luta por justiça social e democratização da sociedade. Um marco na atuação da Igreja foi a realização do Encontro Inter-regional dos Bispos da Amazônia, no Estado do Pará, em maio de 1972. Dentre os movimentos surgidos nesse processo, destacou-se o Movimento dos Atingidos por Barragens - MAB, que, embora de caráter nacional, teve suas raízes na região, nas lutas das populações atingidas com a construção da hidroelétrica de Tucuruí, no Pará (MAB, 2002).

Em depoimento a Corrêa (2007, p. 62), uma liderança do MAB relata que o projeto de Tucuruí representou "o rompimen- to da vida de todo esse povo que perdeu sua terra, sua sobrevivência, suas raízes, suas culturas, suas histórias de vida”. Foi assim que, segundo Diegues (1999, p. 56): “as tensões afloradas pelo processo de desalojamento de seus sítios, em boa parte herdados pela linhagem familiar, estiveram na base do início da resistência contra o processo expropriatório”. Foi assim que, em 1981, com apoio dos Sindicatos de Trabalhadores Rurais - STRs, CPT, CEBs, constituiu-se o Movimento dos Expropriados pela Barragem de Tucuruí:

[...] a luta das populações atingidas por barragens que no início era pela garantia de indenizações justas e reassentamentos, logo evolui para o próprio questionamento da construção da barragem. Assim, os atingidos passam a perceber que além da luta isolada na sua barragem, deveriam se confrontar com um modelo energético nacional e internacional. Para isso, seria necessária uma organização maior que articulasse a luta em todo o Brasil (MAB, 2002, p. 7).

Segundo Porto-Gonçalves (2005), o MAB conseguiu posicionar as populações locais, de um lado, como atingidos pela política de desenvolvimento do Estado e, de outro, como sujeitos, protagonistas de outras propostas e ações. Com a construção da barragem de Tucuruí, as lutas do MAB e dos atingidos seguiram, mas o Estado não sustou seu projeto de avançar na exploração hidráulica na região.

Um outro momento dessa política de expansão teve início com o Inventário $h i$ drelétrico do rio Xingu, documento produzido em 1980, pelo Consórcio Nacional de Engenheiros Consultores S.A - CNEC, vinculado à Camargo Corrêa. Esse documento provocou reação de diversos setores, 
nos planos local, nacional e internacional, em particular dos povos indígenas da região do rio Xingu e de cientistas (SWITKES; SEVÁ FILHO, 2005). Foram previstas, conforme assinalam Zachary Hurwitz et al. (2011), cinco hidrelétricas no rio Xingu (Jarina, Kokraimoro, Ipixuna, Babaquara e Kararaô) $)^{6}$ com uma capacidade instalada de 20.000 MW e com potencial de inundar cerca de $18.000 \mathrm{mil} \mathrm{km}^{2}$. Switkes e Sevá Filho (2005, p. 14) avaliaram, entre as áreas a serem alagadas, as "glebas ribeirinhas incluídas em várias Terras Indígenas já homologadas, algumas delimitadas mas invadidas, outras ainda não homologadas”. 0 Instituto Socioambiental - ISA ${ }^{7}$, em seu retrospecto acerca de Belo Monte, assinala que em 1980, a partir das recomendações do Inventário, a Eletronorte inicia os estudos de viabilidade técnica e econômica desse Complexo Hidrelétrico, em especial quanto a Kararaô (11 mil MW).

Entretanto, conforme indicado, já vinha se constituindo na região, a partir de importante ação de segmentos da Igreja Católica, um ambiente de mobilização e organização popular, que favoreceu a articulação da resistência. Uma liderança do Movimento de Mulheres do Campo e da Cidade do Pará - MMCC, atuante em Altamira, em entrevista, comenta a esse respeito:

A igreja começou a fazer com que nós, lideranças, pudéssemos refletir a partir da palavra de Deus, essa questão das nossas necessidades. A igreja católica foi a base pra organização social e política dos movimentos. Ela foi o alicer- ce das discussões. Porque, nós íamos pra celebrar e a partir da palavra vinham as discussões de organizar e formar sindicatos, partido: "vamos fundar o movimento tal pra lutar por isso e mais aquilo". Então, a igreja foi fundamental no alicerce do surgimento e da organização dos movimentos sociais ${ }^{8}$.

Outra entrevistada integrante do MMCC evidencia as conexões que passaram a se estabelecer entre as CEBs, o PT, os STRs, o MMCC e várias outras organizações e movimentos populares de resistência:

Então, em 1989, eu já militava no Partido [dos Trabalhadores], porque as CEBs diziam assim: "0 militante comprometido com a justiça deve estar filiado a um partido político comprometido com a justiça”. Então, me filiei no PT [risos] por esse compromisso das CEBs (...) Então, todos ergueram a bandeira, essa bandeira da agricultura familiar, a bandeira das políticas públicas, dos direitos e contra Belo Monte. Contra Kararaô, na época, e depois contra Belo Monte. Belo Monte não era o projeto pensado pelos trabalhadores, nem apoiado pelos trabalhadores, nem pelas lideranças, como projeto de desenvolvimento pra região, nunca foi ${ }^{9}$.

Na Amazônia e no Xingu, posicionaram-se - no contexto dos anos 1980 - de um lado, a referência ufanista dos grandes projetos, nutrida por grandes proprietários rurais, políticos, empresários e tecnocratas; e, de outro, os povos indígenas, populações ribeirinhas, camponeses, que se sentindo

6. E uma sexta, no rio Iriri, de nome Iriri.

7. Organização da Sociedade Civil de Interesse Público - OSCIP, sediada em São Paulo, que tem adotado posições em contrário à construção da hidroelétrica Belo Monte.

8. Entrevista dada a Sérgio Corrêa, em junho de 2012.

9. Entrevista concedida a Sérgio Corrêa, em junho de 2013. 
ameaçados em seus territórios e modos de vida passaram a se mobilizar e a se articular, por meio de movimentos, partidos e ONGs, em âmbito local, nacional e internacional.

Em 1989, a realização do $1^{\circ}$ Encontro dos Povos Indígenas do Xingu, em Altamira, tornou-se um marco da resistência a tais projetos, em especial ao Kararaô. Conforme o ISA $^{10}$, os fios desse encontro começaram a ser puxados um ano antes, com a ida do pesquisador Darrel Posey, do Museu Emílio Goeldi, e das lideranças indígenas kaiapó Paulinho Paiakan e Kuben-I para os EUA, com vistas a apresentarem denúncia de que o Banco Mundial aprovara financiamento para a construção de hidrelétricas no Rio Xingu sem consulta aos índios. Em seguida, a apresentação foi repetida em São Paulo, no Centro Ecumênico de Documentação e Informação - CEDI. Articulações passaram a ocorrer em torno do tema, com importante mediação do CEDI e da Comissão Pró-Índio de São Pau$10^{11}$. 0 Encontro reuniu três mil pessoas, das quais 650 eram índios. Ganhou repercussão internacional com o "gesto de advertência da índia kaiapó Tuíra, que tocou com a lâmina de seu facão o rosto do então diretor da Eletronorte, José Antônio Muniz Lopes”13. Além de expressar seu protesto contra a construção das hidrelétricas na região, colocou em evidência a exclusão dos povos indígenas nas tomadas de decisões sobre a Amazônia. Apoiado por uma rede de movimentos sociais da Transamazônica e de organizações sociais e ativistas ambientais nacionais e internacio- nais, tal evento culminou na suspensão temporária desses projetos.

Uma liderança do STR de Altamira, em entrevista, comentou sobre a emergência de um novo protagonismo dos povos indígenas do Xingu:

Foram eles [indigenas] que se mobilizaram, se uniram para protestar e parar aquele primeiro projeto, chamado Kararaô. Mas, isso foi feito com apoio de outros movimentos sociais da região da Transamazônica. Essa região, principalmente com os grandes projetos da década de 70 do regime militar, trouxe muitos migrantes, inclusive eu, vindo do Espírito Santo, em busca de terra e de trabalho, de melhor condição de vida. Com os grandes projetos, vieram grandes problemas sociais e ambientais e com isso a necessidade de organizar o povo do campo pra lutar pelos seus direitos. Então, com apoio da igreja, começamos a nos organizar, fazendo dessa região um palco de muita luta contra as opressões dos latifundiários ${ }^{13}$.

Entre fins dos anos 1980 e início dos 1990, a dinâmica de mobilização e articulação sindical e popular se reconfigura, ao ganhar maior amplitude e complexidade, quando emergem novos atores e demandas sociais, com a questão ambiental passando a se compor com a questão social.

Para Henchen e Magalhães (2012, p. 15), isso evidencia um processo de ambientalização dos conflitos ${ }^{14}$ da Amazônia, que

10. Ver http://www.socioambiental.org/esp/bm/index.asp . Acesso em 12 fev. 2013.

11. Ver http://www.cpisp.org.br/html/sobre_cpi.html. Acesso em 13 dez. 2013.

12. Ver http://www.socioambiental.org/esp/bm/index.asp . Acesso em 11 nov. 2013.

13. Entrevista concedida a Sérgio Corrêa, em junho de 2012.

14. Um fenômeno que, para Lopes (2006.p. 32), suscita uma nova questão social, com a emergência da questão ambiental como nova fonte de legitimidade e de argumentação nos conflitos: "Tanto trabalhadores quanto partes das populações atingidas por danos ambientais passam a utilizar-se também da questão ambiental como repertório de seus interesses e reivindicações”. 
trouxe um envolvimento dos camponeses com a proposta ecológica:

A partir do momento em que os mediadores camponeses assumiram a tarefa de constituir uma organização federadora (Sic!), o MPST, no final da década de 1980, formou-se uma nova configuração no cenário regional, e desta nova configuração de forças emergia um novo ator social, para o qual, o desenvolvimento sustentável significava, acima de tudo, sua própria subsistência enquanto categoria social. Tínhamos então na luta pela classificação, para impor uma ou outra forma de recortar o espaço social, para unificar ou dividir, a emergência do camponês agroecológico, testemunhado pelas iniciativas de proteção de nascentes de igarapés, pelos sistemas agro-florestais, pelas roças sem queimar, pelos grupos de camponeses produtores de cacau orgânico.

Em 1991, foi realizado o encontro intitulado "A luta pela sobrevivência na Transamazônica”, promovido pelos movimentos e organizações sociais, no qual denunciaram o "estado de abandono da Transamazônica”, discutindo os temas da saúde, educação, crédito agrícola, meio ambiente, energia, urbanização e infraestrutura. Nesse momento, foi pautada a defesa do Projeto Global de Desenvolvimento da Transamazônica - PGDT e ofıcializado o Movimento pela Sobrevivência da Transamazônica MPST. Em seguida foi constituída a Fundação Viver Produzir e Preservar - FVPP, o "braço jurídico" do MPST. Conforme avaliação das lideranças, "esse nome carregava um apelo autêntico e identificado com os anseios da população, e potencializava a mobilização das amplas camadas insatisfeitas com o abandono" (FVPP, 2006, p. 25) ${ }^{15}$. Também em 1991 se constituiu o Movimento de Mulheres Trabalhadoras de Altamira Campo/Cidade, vinculado ao MMCC.

No final de 1998 e início de 1999, o MPST entende que a luta deve ir para além da questão da sobrevivência, pautando em seu repertório o tema do modelo de desenvolvimento. Ademais, considera que sua ação não podia mais se restringir aos municípios da Transamazônica, sendo estratégico abarcar os municípios da bacia do Xingu, haja vista a retomada do projeto da hidroelétrica de Belo Monte. Daí surgiu o Movimento pelo Desenvolvimento da Transamazônica e Xingu - MDTX (FVPP, 2006).

Nos anos 1990, contudo, havia se projetado no País a agenda neoliberal e o discurso da globalização. Suas repercussões se fizeram sentir no setor elétrico, que passou por reformas e privatizações. A política energética, via grandes empreendimentos hidrelétricos, voltou a assumir lugar estratégico na agenda oficial e o projeto Kararaô foi retomado. Conforme Switkes e Sevá Filho (2005, p. 15):

Até 1999, a empresa [Eletronorte] foi, em geral discretamente, intensificando a implantação do projeto: fez modificações geográficas e técnicas relevantes no projeto, rebatizou-o pela $2^{\text {a }}$ vez, agora seria o CHBM - Complexo Hidrelétrico de Belo Monte, somente com as obras da $1^{\text {a }}$ usina na Volta Grande. Passou a chamar de Usina ou Aproveitamento Altami-

15. Em abril de 1991, foi realizado o primeiro Grito do Campo, um ato de mobilização de trabalhadores rurais que surgiu no Estado do Pará. Em 1992, esse evento se expandiu para os estados da Amazônia e, a partir de 1994, ganhou dimensão nacional, com a denominação de "Grito da Terra Brasil” (FVPP, 2006, p. 26). 
ra a anterior usina Babaquara, mas desmentia que iria fazê-la, insistindo que Belo Monte tinha viabilidade mesmo que fosse um barramento "isolado" no rio Xingu.

Em 2000, a Eletronorte firma contrato com a Fundação de Amparo ao Desenvolvimento da Pesquisa - FADESP, do Pará, para elaborar Estudo de Impacto Ambiental-EIA e Relatório de Impacto Ambiental - RIMA sobre o projeto Belo Monte. Todavia, sob o argumento de irregularidades, o Ministério Público Federal do Pará - MPF, em 2001, ajuizou uma Ação Civil Pública, a partir da demanda feita pela "sociedade civil da região da Transamazônica e do Xingu” (PONTES JÚNIOR e BELTRÃO, 2005, p. 74). Com isso, o Poder Judiciário decidiu pelo embargo do EIA-RIMA e do processo de licenciamento ambiental. Em 2002, o Complexo Hidrelétrico de Belo Monte foi suspenso mais uma vez. Nesse momento, ganhou evidência o papel do MPF.

Antônia Melo, à época, uma das lideranças do MDTX, denuncia tentativas da Eletronorte de naquele momento "aliciar" lideranças e gestores públicos locais, visando esvaziar a resistência ao projeto:

A Eletronorte articulou o apoio do comércio local, através da ACIAPA - Associação Comercial Agropastoril de Altamira, da AMEALT - Associação dos Micro-Empresários de Altamira, do CDL - Clube de Dirigentes Lojistas, do Sindicato Patronal dos Produtores Rurais, da AMUT - Associação dos Municípios da Transamazônica, e também o apoio dos Vereadores da Região, principalmente os ligados ao PSDB e PMDB. Os então prefeitos Domingos Juvenil, de Altamira (PMDB), Anselmo Hoffman, de Vitória do Xingu (PT), Gerson Campos, de Porto de Moz (PSDB), Mário Lobo, de Uruará (PSDB), João Escar- pario, de Placas (PSDB), e Antonio Lorezoni, de Brasil Novo, congregaram-se no chamado Consórcio Intermunicipal Belo Monte, que foi articulado pelo ex-presidente da Eletronorte, José Antonio Muniz Lopes, e outros políticos do grupo Sarney (MELO, 2005, p. 56).

\section{Na Carta SOS Xingu: um chamamento ao} bom senso sobre o represamento de rios na Amazônia, de 25 de julho de 2001, o MDTX alerta para a prática do "aliciamento" da opinião pública sob as "velhas e conhecidas promessas de progresso para todos", além de não ser transparente e não abrir o debate público sobre o tema (apud SEVÁ FILHO, 2005, p. 317). Além da oposição ao projeto de Belo Monte, o MTDX reivindica a implementação de um projeto de desenvolvimento sustentável, tendo como base a agricultura familiar, a criação de reservas florestais, financiamento para a educação e a eletrificação rural, proteção das terras indígenas e a viabilização de políticas e atividades econômicas sustentáveis para as populações tradicionais. Do ponto de vista das questões social e ambiental, um balanço da década anterior teve, em leituras como a de Camargo, Capobianco e Oliveira (2002, p. 21), a marca da negatividade, mas também de ações simbólicas por parte do governo supostamente indicando alguma incorporação das demandas da sociedade:

Os anos pós-Rio 92, fortemente marcados pela crise econômica e o Plano Real, ensejaram uma hegemonia economicista nas discussões sobre o futuro do Brasil e na leitura da mídia sobre os problemas nacionais. As chamadas reformas econômicas se impuseram sobre as demandas sociais e ambientais. Neste período, imperou uma estratégia de governo fundamentada na inserção do Brasil na economia mundial, em processo acelerado de globalização, através da que- 
bra de barreiras comerciais e à circulação de capitais, privatizações e abertura da economia para o capital externo. 0 esforço básico da diplomacia e das relações internacionais foi para criar e manter a imagem de um país estável, atento às agendas e demandas multilaterais, de modo a remover obstáculos legais, políticos ou até simbólicos, que pudessem afugentar investimentos ou capitais de ocasião. Foi neste contexto que questões relacionadas ao meio ambiente, aos índios $\mathrm{e}$ populações tradicionais, aos conflitos fundiários ou aos direitos humanos, foram incorporadas à estratégia política do governo federal. A ênfase nestas políticas, no entanto, ficou limitada à sua função simbólica, ao seu eventual possível impacto de mídia, sem que se tenha estabelecido uma agenda consistente de ações dirigidas à efetiva solução do desenvolvimento sustentável, dependente de reformas profundas nas estruturas de governo, da sociedade e da cultura.

Em carta ao Presidente Fernando Henrique Cardoso, de março de 2002, o MTDX denuncia o retorno dos projetos de hidrelétricas no rio Xingu e Amazônia:

É um projeto insano, na contramão da história e um atentado com a Amazônia. Sr. Presiden-

te, chamamos sua atenção para a importância da decisão e os métodos com os quais seu Governo está decidindo sobre o futuro ecológico dessa região e suas consequências para a Amazônia e para os estoques de água doce do planeta. Nós queremos discutir, com o tempo e os cuidados necessários, o que representa $o$ represamento dos rios da Amazônia, diante do valor estratégico das águas no milênio que se inicia (...) Diante desses pontos de vistas, Sr. Presidente, é preciso ouvir outras vozes que não apenas a tecnocracia da Eletrobrás. Saber mais da história das hidrelétricas na Amazônia. Não convém colocar em jogo o futuro da Amazônia, para responder eleitoralmente para as regiões industrializadas, deixando aqui o caos social causado por um empreendimento dessa envergadura. Ousamos fazer nosso próprio projeto de desenvolvimento. Isso é modernidade, Sr. Presidente: a sociedade local pensar políticas públicas e dialogar com seu governo sobre o futuro de uma região (apud SEVÁ FILHO, 2005, p. 325).

Para Campagnolo (2007), ocorria um deslocamento da resistência popular, da esfera da ação coletiva para a arena da ação judicial - sugerindo um processo de judicialização, evidenciado, por exemplo, com a centralidade da Ação Civil Pública do MPF na suspensão do EIA de Belo Monte, em $2002^{16}$. Tal processo tem assinalado

16. Conforme observa Motta (2012, p. 204-205): “O Ministério Público Federal ilustra bem essa perspectiva relacional do Estado - no que se refere aos limites legais apontados por Poulantzas haja vista as múltiplas ações que vêm desempenhando nos últimos anos em termos de absorção das demandas da sociedade, ou representando os interesses da sociedade civil, seja ela organizada ou não. Suas ações estendem-se a diversos campos como a improbidade administrativa, a defesa do meio ambiente, dos direitos humanos, na área do consumidor, ou seja, o leque é muito amplo em termos de representação. Talvez há vinte anos, se falássemos de danos ambientais, ou a questões vinculadas ao preconceito racial ou de gênero, talvez o cidadão consciente de seus direitos viesse a procurar os partidos políticos como canal de representação da defesa de seus interesses. Hoje, em geral, além das representações funcionais estatais como o Ministério Público, a Magistratura ou a Defensoria Pública, o cidadão individual, e mesmo coletivo, tem demandado pelos novos movimentos sociais, as chamadas ONGS (organizações não governamentais), que também são representações funcionais de caráter societal, na defesa de seus direitos". 
e demonstrado o quanto a esfera institucional (jurídica) se tornou uma das arenas centrais desse campo de batalha. Entretanto, até onde pudemos apurar na pesquisa, o referido protagonismo em especial do MPF não tem implicado no esvaziamento da esfera da ação coletiva do MXVPS contra Belo Monte ou produzido um total deslocamento dessa esfera da sociedade civil para a esfera jurídica. Evidentemente que isso tem ocorrido com certas tensões entre essas arenas.

A resistência histórica aos grandes projetos na Amazônia, em especial aos do setor hidroelétrico, fez-se incorporando novos elementos a cada vez: extensão das articulações às escalas nacionais e internacionais; crescente protagonismo dos povos indígenas em associação com a ambientalização dos conflitos; ampliação e complexificação dos atores sociais, locais e externos, em resistência popular e democrática; esforços de formulação de conceitos e ações alternativas de desenvolvimento; certa judicialização das formas de luta, entre outros. Segmentos populares se constituíram nas lutas travadas em sujeitos políticos, mas nesse processo se modificaram, ao mesmo tempo em que produziram modificações nas ações e estratégias das forças dominantes. Foi assim que o projeto Belo Monte, com a crítica social que continuou sofrendo, foi reeditado pela terceira vez. Em cada uma delas, apoiando-se nas novas formatações adquiridas, os argumentos dos seus defensores (governos, empresários interessados, tecnocratas) foram sendo recompostos, com propósito de justificação social. Ante os argumentos dos contestadores das justificações governamentais e empresariais (os povos indígenas, populações ribeirinhas e atingidos pelas barragens, movimentos sociais, sindicalistas, agências de mediação das lutas de resistência), as formas de luta e de organização, por sua vez, precisaram na sua perseverança, renovar-se, atualizar-se ${ }^{17}$.

\section{Projeto AHE Belo Monte: reposiciona- mento dos atores e ressignificação dos conflitos}

0 projeto Belo Monte foi retomado com o PAC. Switkes e Sevá Filho (2005, p.25) notam que até a eleição de Lula prevalecia uma bem delimitada distinção de forças políticas:

17. Nos termos de Boltanski e Chiapello (2009, p. 515): "Com seus deslocamentos, o capitalismo se reestrutura, livrando-se da crítica. Mas a vantagem assim obtida constituiu um ganho temporário, e não uma vitória definitiva. Mesmo se abstraindo fatores que, do lado da crítica, favorecem sua perenidade, os efeitos destruidores de um capitalismo sem freios criam, por si mesmos, um terreno favorável à retomada da crítica. Isso ocorre ainda que o momento e a modalidade dessa transformação dependam da conjuntura histórica e tenham, por isso, caráter imprevisível, de tal modo que sua manifestação na maioria das vezes é acolhida como uma 'surpresa' que vem invalidar as previsões e as projeções dos futurólogos (...) A retomada da crítica muitas vezes ocorre de um ponto de vista anacrônico, que julga o presente pelos padrões de ideais do passado. Mais precisamente, a crítica assume então a forma de defesa conservadora das provas regulamentadas para cuja maior tensão (maior justiça) os movimentos sociais anteriores haviam contribuído. Num segundo momento, diante do caráter aparentemente inelutável dessa inversão das ordens de grandeza, a vigilância crítica se orienta para a busca das razões de tal fenômeno, ou seja, mais precisamente, para a identificação das novas provas e das forças excedentes e ocultas que garantem o sucesso. Progressivamente, reconstituem-se esquemas de interpretação que possibilitam dar sentido às mudanças em curso e abrem caminho para uma crítica mais específica às novas provas e à formulação de reivindicações e propostas orientadas para um horizonte de justiça”. 
Durante os anos 1990 e no começo da década atual [2000], a polarização política e partidária que se formou em Altamira e no Pará a propósito desse mega-projeto, indicava quase sempre os parlamentares e candidatos dos partidos então considerados de esquerda, o PT, PC do B, PSB, como sendo opositores do Belo Monte e, por simetria, eram a favor da obra os partidários locais e regionais dos governos estaduais do PMDB (J. Barbalho) e depois do PSDB (A. Gabriel e S. Jatene), alinhados, neste caso, com o governo federal na era Cardoso-Maciel.

Com o novo Governo, no plano Federal, não obstante sua relação histórica e simbólica com os movimentos sociais e as lutas pela democratização da sociedade brasileira, o projeto foi retomado:

Em 2001 e 2002, todos que acompanhavam o caso tinham a sensação de que uma vitória do candidato Lula poderia sepultar o projeto Belo Monte e os demais que eram mantidos na berlinda exatamente pelos políticos e militantes da antiga oposição. Mas não! Uma das razões é que, durante os primeiros meses do novo governo, em 2003, o senador José Sarney, aliado do governo Lula, convencia a cúpula federal da importância e oportunidade do projeto Belo Monte. No início de 2004, mostrou que ainda comandava o seu feudo na máquina federal, provocando a troca de presidente da Eletrobrás, que é a empresa acionista principal da Eletronorte e das outras geradoras estatais Furnas e Chesf (SWITKES e SEVÁ FILHO, 2005, p. 25).

Para Hurwitz et al. (2011, p. 22), no início, houve no entanto muita cautela:

[...] Belo Monte não era considerado prioridade [nos dois primeiros anos do Gover- no Lula] em discussões internas do Governo Federal sobre a abordagem de obras de infraestrutura no Plano Amazônia Sustentável (PAS) e sua articulação com o Plano Pluri -Anual (PPA) 2004-2007. No início de 2004, um documento do Ministério da Integração Nacional, elaborado em conjunto com o Ministério do Meio Ambiente, com o Ministério do Planejamento e com a Presidência da República, identificou como riscos e fatores negativos de Belo Monte a "abertura de frente de ocupação em região vulnerável", "grande oposição" de entidades da sociedade civil na região e "conflito de interesses explícito". Foi observado ainda que o empreendimento “não é prioridade do governo estadual". Por fim, recomendou-se que "a obra deve ser objeto de reavaliação" e que "não se deve considerar a possibilidade de apoio no curto prazo (com recursos públicos)”.

Contudo, em julho de 2005, a Câmara Federal autorizou os estudos para a implantação do projeto de AHE Belo Monte. Em seguida, também o foi pelo Senado, seguindo para a promulgação presidencial sem que os povos indígenas e as populações ameaçadas tivessem sido ouvidos. Ainda em julho, a Coordenação das Organizações Indígenas da Amazônia Brasileira - COIAB, o ISA, o Greenpeace e o Centro dos Direitos das Populações da Região do Carajás acionaram o MPF para que os povos indígenas fossem consultados e ouvidos.

Um novo embate se estabeleceu. Agora, com um maior esforço de convencimento, por parte das empresas e agentes públicos envolvidos, sob argumentos técnicos e um proeminente apelo à ideia de "sustentabilidade”. Por exemplo, a Empresa de Pesquisa Energética - EPE (2011, p. 2) destacou uma maior "eficiência" da última formulação do projeto, além de maior "proteção social e 
ambiental", através de medidas que "incluem uma redução da área alagada do reservatório de $1.225 \mathrm{~km} 2$ para $516 \mathrm{~km}^{2}$ ". Defendeu as mudanças no projeto como uma "abordagem inovadora", tendo como marcas: "Projeto Nacional”, "Parceira Público -Privada” (com o Consórcio Norte Energia), "Desenvolvimento Sustentável” e "Energia Limpa”. Também o então Ministro de Minas e Energia, Edson Lobão, foi categórico em afirmar que "nenhuma das reservas indígenas existentes em torno da área do empreendimento será alagada" e que "nenhum dos cerca de 1,6 mil índios terá que sair de onde se encontram hoje" ${ }^{18}$. Do mesmo modo o BNDES, destacado financiador do projeto, passou a sustentar sua importância para o desenvolvimento do país ${ }^{19}$. Quanto à Eletrobrás, a defesa do projeto foi formulada nos seguintes termos:

Para o seu desenvolvimento, o Brasil precisa de energia limpa e renovável com o menor custo para a sociedade. Nesse contexto, o projeto da hidrelétrica de Belo Monte, no rio Xingu, é uma das melhores opções para a ampliação do parque gerador brasileiro, pois permite grande produção de energia e apresenta uma condição muito favorável de integração com o sistema elétrico nacional [...] Isso contribuirá para o aumento da oferta de energia e da segurança do sistema elétrico ${ }^{20}$.

Grupos empresariais nacionais e transnacionais (empreiteiras, mineradoras $\mathrm{e}$ outras) passaram a defender o significado estratégico dessa obra para expandir e melhorar a infraestrutura do País, a fim de possibilitar o aumento de sua produtividade e competitividade. A Norte Energia - NESA, empresa responsável pela construção do empreendimento de Belo Monte, em conjunto com o Consórcio Construtor Belo Monte - CCBM, em um esforço evidente de incorporação e neutralização da crítica social produzida na região nas últimas décadas, lançou-se na defesa de sua viabilidade econômica, social e ambiental ${ }^{21}$. Em sua Cartilha: “Conheça a UHE Belo Monte”, com tais argumentos, apresenta defesa articulada do empreendimento ${ }^{22}$.

No plano local, os defensores do projeto buscaram realçar a dinamização da economia, a geração de emprego e renda, a redução da pobreza. Políticos de diversos matizes convergiram para tal posição. Ganhou peso o Fórum Regional de Desenvolvimento Econômico e Socioambiental da Transamazônica e Xingu - FORTXingu, composto por instituições locais, em geral empresariais:

Mais do que gerar 11.233 MW de eletricidade para abastecer 17 Estados por meio de 27 distribuidoras, 18 milhões de residências e garantir energia a preços módicos para 60 milhões de pessoas, a construção de Belo Monte significa oportunidade singular de emprego, renda e de melhorias na arrecadação dos onze municípios situados no entorno da obra, além de uma centena de compensa-

18. Ver http://memoria.ebc.com.br/agenciabrasil/noticia/2011-06-01/usina-de-belo-monte-comecarafuncionar-em-2015-garante-lobao . Acesso em: 21 jan. 2014.

19. Ver http://new.livestream.com/accounts/2091831/events/1961260. Acesso em 15 mai. 2014.

20. Ver http://www.eletrobras.com/elb/ri/data/Pages/LUMIS46763BB8PTBRIE.htm . Acesso em 21 jan. 2014.

21. Ver http://norteenergiasa.com.br/site/ e http://blogbelomonte.com.br/ . Acesso em 18 mai. 2014.

22. Ver http://www.blogbelomonte.com.br/wp-content/uploads/2011/12/Cartilha_portugues_.pdf. Acesso em 18 fev. 2014. 
ções sociais e ambientais comprometidas para cada uma dessas localidades ${ }^{23}$.

Importante destacar que esse alinhamento de atores em favor do projeto Belo Monte não se constitui de modo harmônico, haja vista as diferenças de interesses em disputa. Um exemplo disso é a própria posição assumida pelo FORT-Xingu de crítica à demora do governo federal em implementar as ações de compensação nos municípios da área de influência do projeto.

Em janeiro de 2006, com base em autorização do Congresso, a Eletrobras formalizou, junto ao Ibama, novo pedido de abertura do processo de Licenciamento Ambiental Prévio, iniciando também o EIA. O MPF, por sua vez, moveu nova Ação visando suspender, liminarmente, os procedimentos do Ibama no caso. Em março, o pedido da Eletrobras foi suspenso pela Justiça Federal de Altamira, impedindo a continuidade do EIA, dado que os povos e comunidades ameaçadas pelo projeto não tinham sido informados e consultados.

Em janeiro de 2007, o Governo Federal lançou o PAC, tornando-se um divisor de águas na nova agenda do desenvolvimento do país, em particular para a Amazônia. Em 2008, a participação das empreiteiras Camargo Corrêa, Norberto Odebrecht e Andrade Gutierrez foi autorizada nos EIA do projeto Belo Monte pelo Tribunal Regional Federal de Brasília, que suspendeu a liminar da Justiça Federal de Altamira. O MPF, diante disso, questionou e recorreu, defendendo procedimento de licitação para a seleção dos responsáveis pelo EIA-RIMA.
Ainda em 2008, após 19 anos do primeiro, foi realizado o II Encontro Xingu Vivo para Sempre, também em Altamira, reunindo representantes de povos indígenas e de comunidades tradicionais e camponeses, ONGs e pesquisadores, para debater os impactos dos projetos de hidrelétricas na Bacia do Rio Xingu. Na ocasião, foram denunciadas as ameaças às populações que vivem do rio e reafirmada uma perspectiva alternativa de desenvolvimento ${ }^{24}$. Sobre o evento, uma liderança do MXVPS, entrevistada, observou:

Em 2008, os indígenas, vendo que o governo avançava, que o governo Lula avançava, para implantar Belo Monte no Xingu, os indígenas convidaram, no início de 2008, os movimentos sociais da região, convidaram os agricultores, ribeirinhos, pescadores e os indígenas daqui do médio Xingu, para um grande encontro no modelo do encontro de 89. Eles queriam discutir o que era esse projeto Belo Monte, eles queriam saber porque o governo já estava implantando e eles não tinham sido ouvidos, não tinham sido consultados, conforme diz a lei, e quanto mais os movimentos sociais! $!^{25}$.

Outra liderança do MXVPS comentou:

[...] as organizações que participaram desse segundo grande encontro, dentro do encontro, percebem que elas poderiam fazer muito mais se elas conseguissem dialogar de forma mais próxima, mais sistemática, dentro de um coletivo onde todos pudessem estar discutindo juntos e definindo juntos o que fazer a par-

23. http://blogbelomonte.com.br/2012/09/01/fort-xingu-belo-monte-e-comunidades-indigenas/ . Acesso em 19 fev. 2014.

24. Ver site http://www.xinguvivo.org.br/2010/10/14/historico/ . Acesso em 18 fev. 2014.

25. Entrevista a Sérgio Corrêa, em junho de 2013. 
tir da área de atuação de cada entidade. Por exemplo, o CIMI atuando junto aos indígenas; o Sindicato de Trabalhadores Rurais, seja de que município for da área de influência de Belo Monte, trabalhando junto aos agricultores; Colônia de Pescadores trabalhando com os pescadores; as Organizações NãoGovernamentais de atuação na área de educação, assistência social, trabalhando em sua respectiva área. Ou seja, pegar o que cada organização dominava e agia e juntar todas essas peças num coletivo que pudesse estar fortalecendo a luta. Pautar uma agenda e uma metodologia, uma estrutura de fortalecimento das ações individuais de cada organização ou entidade. 0 objetivo final seria: a partir da somatória de forças, ter resultados melhores, visto que a luta contra a construção de Belo Monte é uma luta contra interesses que vêm do governo federal, governo estadual e governos municipais, empresas mineradoras e empreiteiras, políticos poderosos. Então, é uma luta contra poderes muito grandes! ${ }^{26}$

Uma outra liderança do Movimento acrescenta que "assim foi criado o Movimento Xingu Vivo para Sempre, coletivo que hoje conta com mais de 250 organizações" (MONTEIRO, 2012).

0 Bispo da Prelazia do Xingu, Dom Erwin Kräutler, abriu II Encontro: "Mais de seiscentos indígenas, mulheres, homens e crianças, entraram solenemente no recinto, cantando e dançando, erguendo suas lanças, bordunas e facões" 27 . No segundo dia, um fato marcou o evento:
Quando, após a palestra do engenheiro, o representante do Movimento dos Atingidos por Barragens, iniciou sua fala dizendo que os índios irão defender o Xingu para protegê -lo, ressoou de repente pelo ginásio um terrivel grito de guerra. Os índios se levantaram e ergueram bordunas e facões e, em seguida, iniciaram uma dança movimentando-se em direção ao engenheiro. Vi os índios gesticularem com facões e bordunas. Simbolizaram um ataque. Do lugar onde eu estava, não pude observar que um dos facões resvalou no braço do engenheiro, ferindo-o [...] 0 engenheiro foi encaminhado para o hospital, levou seis pontos e recebeu alta [...] Nós, da coordenação e responsáveis pelo evento, ficamos espantados, muito aflitos e angustiados ao extremo. Imaginávamos logo a repercussão do acidente nos meios de comunicação ${ }^{28}$.

Ao final, o MXVPS divulgou carta questionando o fato de não estar sendo consultado sobre o projeto Belo Monte e denunciando o modelo de desenvolvimento dominante:

Não admitiremos a construção de barragens no Xingu e seus afluentes, grandes ou pequenas, e continuaremos lutando contra o enraizamento de um modelo de desenvolvimento socialmente injusto e ambientalmente degradante, hoje representado pelo avanço da grilagem de terras públicas, pela instalação de madeireiras ilegais, pelo garimpo clandestino que mata nossos rios, pela ampliação das monoculturas e da pecuária extensiva que desmatam nossas florestas ${ }^{29}$.

26. Entrevista concedida a Sérgio Corrêa, em março de 2012.

27. Ver http://www.cnbb.org.br/articulistas/dom-erwin-kraeutler/2583-os-povos-indigenas-do-.xingu-e -a-hidreletrica-belo-monte . Acesso em 18 fev. 2014.

28. Ver http://www.cnbb.org.br/articulistas/dom-erwin-kraeutler/2583-os-povos-indigenas-do-.xingu-e -a-hidreletrica-belo-monte . Acesso em 18 fev. 2014.

29. Ver http://www.equit.org.br/novo/wp-content/uploads/2013/03/cartadoxingu.pdf . Acesso em 18 fev. 2014. 
Entre várias medidas visando a reorientação de tal modelo, o encontro aprovou a criação de um fórum de articulação dos povos da bacia para permitir uma negociação permanente sobre o futuro do rio e avançar na criação de um Comitê de Bacia do Xingu. Finalizou com:

\begin{abstract}
Nós, os que zelamos pelo nosso rio Xingu, não aceitamos a invisibilidade que nos querem impor e o tratamento desdenhoso que o poder público tem nos dispensado. Nos apresentamos ao país com a dignidade que temos, com o conhecimento que herdamos, com os ensinamentos que podemos transmitir e o respeito que exigimos. Esse é o nosso desejo, essa é a nossa luta. Queremos o Xingu vivo para sempre ${ }^{30}$.
\end{abstract}

Em entrevista, em 2009, Edson Lobão, contra-atacou: "as hidrelétricas não podem ficar paralisadas por queixas de ONGs ou do Ministério Público, ou do que quer que seja. É preciso que haja uma decisão judicial, com rapidez" ${ }^{31}$. Em resposta à declaração do Ministro de que "a sociedade não pode ser penalizada com energia mais cara, porque os ambientalistas e ONGs atrapalham a construção das hidrelétricas”, o MXVPS retrucou: "Como pode afirmar que a energia de Belo Monte será mais barata se os estudos de viabilidade econômica não foram entregues pelo consórcio à sociedade?", criticando os procedimentos não democráticos de implementação do projeto Belo Monte e do modelo de desenvolvimento que expressa ${ }^{32}$.

Em maio de 2009, o EIA-RIMA foi concluído pela Eletrobras e entregue ao Ibama para análise, sendo por este órgão aprovado. Logo em seguida, o MPF entrou com nova Ação, propondo a anulação da aprovação. 0 juiz federal de Altamira aceitou parcialmente o pedido.

Em julho de 2009, Lula recebeu lideranças dos povos indígenas, movimentos sociais e apoiadores, para uma audiência sobre Belo Monte. Na pauta, denúncias sobre viabilidade econômica e consequências socioambientais. Ao final, em carta, o MXVPS informou que se firmara o compromisso de que o governo federal "não enfiaria Belo Monte de goela abaixo" e que se comprometia a responder aos questionamentos apresentados ${ }^{33}$.

0 EIA foi definitivamente aprovado em agosto. Em seguida, o Ibama publicou o edital de audiências públicas ${ }^{34}$ : Brasil Novo, no dia 10 de setembro; Vitória do Xingu, no dia 12; Altamira, no dia 13; e Belém, no dia $15^{35}$. Sobre a audiência em

30. Ver http://www.equit.org.br/novo/wp-content/uploads/2013/03/cartadoxingu.pdf . Acesso em 18 fev. 2014. 31. Ver http://g1.globo.com/Noticias/Economia_Negocios/0,MUL1214925-9356,00.html . Acesso em 15 mai. 2014.

32. Ver http://www.ihu.unisinos.br/noticias/24099-xingu-vivo-para-sempre-divulga-carta-sobre-a-060\%60energia-barata-de-belo-monte\%60\%60. Acesso em 20 mai. 2014.

33. Ver http://xingu-vivo.blogspot.com.br/2010/10/carta-aberta-belo-monte-e-palavra-do.html . Acesso em 15 mai. 2014.

34. Uma condição legal para o licenciamento ambiental.

35. Questionando a "abrangência limitada" das audiências, o MPF moveu mais uma ACP, exigindo que fossem realizadas em 11 dos municipios (PONTES JÚNIOR, 2011). O MXVPS, em carta, denunciou que o EIA completo só foi disponibilizado ao público dois dias antes da primeira audiência, não havendo tempo para uma análise qualificada pelas comunidades atingidas (http://www.xinguvivo.org.br/2010/10/14/historico/. Acesso em 17 jun.2014. 
Brasil Novo, o ISA relatou: "durante quase seis horas foram realizadas apresentações superficiais e questionamentos diversos da população, com respostas quase sempre insatisfatórias" ${ }^{36}$. Antônia Martins, do MMCC, observou: "eu conheço quase todos os agricultores do município e fiquei surpresa de não ver praticamente nenhum conhecido na audiência. A maioria dos presentes eram empresários de Altamira e de Belém" ${ }^{37}$. Em Vitória do Xingu, estiveram presentes mais de 1.500 pessoas, sob forte policiamento. Mais uma vez a audiência foi marcada "pela falta de respostas esclarecedoras” (BARAÚNA; MARIN, 2011, p. 117). Em Altamira, também com a presença de policiamento ostensivo, instalou-se um clima de maior tensão. Para Baraúna e Marin (2011, p. 118), a extravagante presença de um grupo que vestia camisetas com a frase "eu quero Belo Monte", "poderia ser associado aos arranjos políticos em que se constituiu a frente de prefeitos, comerciantes e fazendeiros, entre outros”. Na audiência de Belém, o local de realização foi alterado de última hora, o que levou ao protesto por parte dos representantes dos movimentos sociais, que reivindicavam direito à participação. Um ativista do MXVPS, entrevistado, comentou: "devido à distância, de não sei quantos quilômetros, daqui [Belém] pra Altamira, os caras achavam que aqui não ia ter mobilização nenhuma. Aí surpreendeu o governo, surpreendeu as barrageiras, até que a Força Nacional foi chamada pra reprimir a gente lá” ${ }^{38}$. Conforme Baraúna e
Marin (2011, p. 120), os que defendiam o projeto ocuparam quase todas as cadeiras disponíveis, ficando do lado de fora muitos dos que se colocavam contra: "o espaço da audiência pública foi utilizado para consolidar o projeto". Também os representantes do MP protestaram, argumentando que aquele regulamento não permitia uma “efetiva participação" ${ }^{39}$. Para Magalhães e Hernández (2011, p. 80), “a retórica do 'benefício público" foi "utilizada para legitimar discussões e decisões privadas que colocam o público, interessado e ameaçado, como mero expectador e as instituições como coadjuvantes”. Do ponto de vista do Movimento, ficava evidente o esforço dos patrocinadores do projeto no sentido de esvaziar as possibilidades da crítica social, especialmente advinda da resistência popular e indigena.

Em outubro, pesquisadores de diversas áreas de conhecimento e instituições acadêmicas elaboraram estudo intitulado "Painel de especialistas: análise crítica do estudo de impacto ambiental do aproveitamento hidrelétrico de Belo Monte" ${ }^{40}$, apontando por diversos ângulos problemas no EIA de Belo Monte. Segundo Magalhães et al. (2009, p. 11), foram tidos como subdimensionados "a área diretamente afetada", "a população atingida”, "a perda de biodiversidade”, “o deslocamento compulsório da população rural e urbana”, “o custo social, ambiental e econômico da obra”, além de terem sido negados "os impactos à jusante da barragem principal e da casa de

36. Ver http://www.socioambiental.org/nsa/detalhe?id=2955 . Acesso em 15 mai. 2014.

37. Ver http://www.socioambiental.org/nsa/detalhe?id=2955. Acesso em 15 mai. 2014.

38. Entrevista concedida a Sérgio Corrêa, em maio de 2013.

39. Ver http://www.estadao.com.br/noticias/geral,indios-protestam-contra-belo-monte,435625. Acesso em 15 mai.2014.

40. Sob demanda de movimentos e organizações da sociedade civil. 
força" e negligenciados os riscos "à saúde" e “à segurança hídrica”. 0 documento teria acusado, ainda, "ausência do detalhamento de programas e projetos de mitigação" (MAGALHÃES et al., 2009, p. 33).

Em novembro ainda de 2009, foi realizado o II Encontro dos Povos da Volta Grande do Xingu, na Vila da Ressaca, convocado como audiência pública pelo MP Estadual. $\mathrm{Na}$ ocasião, foi divulgada a Carta dos Povos da Volta Grande do Xingu ${ }^{41}$, denunciando as omissões no Estudo de Impacto Ambiental e no EIA-RIMA. Nesse mesmo mês, a Justiça Federal acatou o pedido do MPF e suspendeu o licenciamento, determinando novas audiências nas quais os povos indígenas e comunidades atingidos fossem informados e consultados. Mas, no dia seguinte, a liminar foi revogada. Em dezembro, após audiência pública na Comissão de Direitos Humanos do Senado Federal, sem a presença do alto escalão do governo, indígenas e ribeirinhos fizeram ato na rampa do Senado contra hidrelétrica de Belo Monte ${ }^{42}$. Dias depois, a Coordenação das Organizações Indígenas da Amazônia Brasileira - COIAB denuncia junto à ONU a violação do direito de consulta livre, prévia e informada, previsto na Convenção 169 da Organização Internacional do Trabalho e na Declaração da ONU sobre os Direitos dos Povos Indígenas, ao mesmo tempo em que solicita que a ONU recomende ao Estado brasileiro que realize as consultas antes do leilão da obra.

Apesar das denúncias, em $1^{\circ}$ de fevereiro de 2010, o Ibama aprova e concede a Licença Prévia ao projeto de AHE Belo Monte $^{43}$. Em 18 de março, o MME anuncia Leilão para 20 de abril. A empresa vencedora foi a Norte Energia S.A - NESA ${ }^{44}$. Em 26 de Janeiro de 2011, foi concedida a Licença Provisória para a implantação do canteiro do projeto ${ }^{45}$. No dia $1^{\circ}$ de junho de 2011, foi concedida a Licença de Instalação de Belo Monte, para implementação completa do projeto e, no dia 23 desse mês, as obras tiveram início.

Contudo, a "guerra" de Belo Monte não chegava ao seu fim. Continuaram as intensas batalhas em diversos campos: socioambiental, político, jurídico, acadêmico, midiático. Visando atuar em todos eles e buscando articular e mobilizar uma ampla, heterogênea e complexa rede de parceiros, o MXVPS se estruturou em quatro frentes de $a c ̧ a \tilde{o} o^{46}$. A Frente jurídica atua identificando as ilegalidades da obra, assumindo importante papel a Sociedade de Defesa dos Direitos Humanos - SDDH do Pará, assim como a parceria com o MPF e entidades internacionais de defesa dos direitos humanos. A Frente cientifica analisa tecnicamente o EIA-RIMA do projeto, tendo como principal parceiro o "Painel

41. Ver http://fase.org.br/wp-content/uploads/2014/08/Carta-dos-Povos-da-Volta-Grande-do-Xingu.pdf . Acesso em 15 mai. 2014.

42. Ver http://www.socioambiental.org/esp/bm/index.asp. Acesso em 17 jun. 2014.

43. Isso levou o MPF a ajuizar a oitava ACP contra o governo em relação a Belo Monte.

44. Conforme a Norte Energia, a composição desse leilão ficou distribuída da seguinte forma: o Grupo Eletrobras (Chesf, Eletrobras e Eletronorte) ficou com 49,98\%; Fundos de Pensão (Petros e Funcef) 20\%; Belo Monte Participações 10\%; Autoprodutoras de Energia (Vale e Sinobras) 10\%; Amazônia (Cemig e Light) 9,77\%; Outras sociedades 0,25\%.

45. 0 deferimento da "licença parcial" pelo Ibama levou o MPF a ajuizar mais uma ACP contra Belo Monte. Ver http://belomontedeviolencias.blogspot.com/search/label/outros\%20artigos . Acesso em 01 fev.2012. 46. Conforme entrevista de um ativista do MXVPS, concedida a Sérgio Corrêa, em maio de 2012. 
de Especialistas”. A Frente de comunicação é responsável por gerir o site do MXVPS, o blog do CMXV, as redes sociais. Quanto à Frente política, faz o trabalho de mobilização e organização da luta.

Não obstante o histórico esforço de construção de alianças e parcerias, em um quadro marcado, no Xingu e na Amazônia, por relações de poder assimétricas, o MXVPS, na resistência à nova versão do projeto Belo Monte, precisou lidar com uma fissura na sua composição. Acerca disso, um ativista do MXVPS, entrevistado, comenta:

Em 22 de junho de 2010, o presidente Lula esteve em Altamira e chamou os militantes do Partido dos Trabalhadores, dizendo que "Quem é do PT não fala contra Belo Monte". Então, todo mundo que era do PT ou que tinha vínculo com o PT e que estava na luta contra Belo Monte, teve que fazer uma opção: ou continuava falando contra Belo Monte, e saia do PT, ou ficava no PT, e parava de falar contra a hidrelétrica de Belo Monte. E muita gente optou por ficar com o PT e calar a voz contra Belo Monte. E muita gente da FVPP fez essa opção, inclusive o Movimento Xingu Vivo foi convidado a se retirar de dentro da Fundação e foi acolhido pela Prelazia do Xingu, onde está hoje, por conta dessa intervenção político-partidária, que foi feita em 2010 [...] Esse foi um duro impacto para o Movimento Xingu Vivo! [...] Agora, é assim. Antes, várias dessas organizações que estavam lá, lutando contra a instalação da hidrelétrica, algumas mudaram de posição, inclusive, passaram a defender a hidrelétrica ou, se não passaram a defender explicitamente, se afastaram da luta por uma questão política, no caso a FVPP foi uma dessas organizações [...] Mas pela vinculação partidária, ao Partido dos Trabalhadores, foi chamada a se reposicionar nessa luta ${ }^{47}$.

Duas posições passaram a polarizar as lideranças que vêm atuando na região, na resistência aos impactos socioambientais de projetos como o de Belo Monte: manter-se totalmente contra sua implementação, mesmo com a construção física já em curso; ou passar a tratar da minimização desses impactos e ou da concessão de compensações às comunidades atingidas. No que se refere à segunda, uma liderança do MMCC e integrante da FVPP, em entrevista, assim a justificou:

É, foi essa agenda mais recente que dividiu um pouco os movimentos, em particular o movimento de mulheres com o movimento Xingu Vivo na região. Porque, no nosso entendimento [FVPP e parte do MMCC], não dá pra deixar os caras [governo federal e Norte Energia] discutirem sozinhos. Se eles vão escutar a gente ou não, a gente não sabe, mas se a gente tiver lá... a gente acredita que nossas ideias são as melhores e foi aí que aconteceu o problema, porque tem uma turma que não aceita de jeito nenhum participar do Comitê Gestor do PDRS [Plano de Desenvolvimento Regional Sustentável do XINGU], de participar de algumas Comissões [...] Eu acho que faltou mais conversa entre nós e o pessoal que tá mais na liderança do Movimento Xingu Vivo [...] Eu tive esse sentimento: é melhor tá do que não tá [inserido nesses espaços como o PDRS $]^{48}$.

A mesma liderança também considera que os movimentos sociais, mesmo diante 
de um governo de esquerda, não pode abrir mão de sua autonomia e capacidade crítica: "É preciso que os movimentos, que têm um vínculo histórico com o PT e com o governo no poder, construam um caminho de independência e de crítica ao governo" ${ }^{49}$.

A respeito do comportamento dos agentes governamentais e empresariais em Belo Monte, vários depoimentos indicam que vêm sendo adotadas medidas de "cooptação” de lideranças. Avaliam que alguns povos indígenas já perderam, em grande medida, suas tradições e costumes, contribuindo assim para deslocar a luta do plano político (defesa de seus territórios e costumes) para o econômico (obtenção de benesses e compensações), e com isso minando sua capacidade de resistência. Um membro da SDDH e assessor do MXVPS, em entrevista, ao contrário de condenar sua aceitação, procura explicá-la:

E aí, em 2010, você tem a licença prévia, em 2011, você tem a licença de instalação e, nesse interim, você tem a emergência dos planos emergenciais e o Plano Básico Ambiental indígena, com componente indígena, aí você tem dinheiro na mão deles. A ideia é: se você não pode barrar Belo Monte, pelo menos se beneficie com o que é possível. Não é uma ideia passiva, não é uma ideia alienada, é uma ideia de quem está nessa luta há 30 anos e sabe o quanto está esgotada a discussão em termos de garantia jurídica, em termos de manter os direitos constitucionais frente a uma obra que tem um autoritarismo ditatorial impactante em termos de que "vai ser feita, vai ser feita e vai ser feita!”. Então, o que eu entendo hoje é que os povos indígenas continuam a ser contrários a Belo Mon- te, mas eles jogam dentro do contexto que é possivel jogar. E, hoje em dia, dados esses recursos que têm chegado a eles, entendem que, de certo modo, "a gente não pode ser contra, vamos aproveitar do que é possível” ou "se a gente não pode mais lutar, vamos pelo menos tentar negociar o que é possível pras nossas aldeias" 50 .

Basicamente, as duas visões se materializam nas posições assumidas. De um lado, pelo MXVPS - que não aceita outro desfecho para o caso senão o da paralisação da obra - e, de outro, pelo MAB - que se mantém próximo a lideranças do PT e do governo. Demarcam-se, assim, posições e concepções diferentes e conflitantes quanto à atuação diante do problema em pauta, pondo como desafio a reconstrução de uma agenda comum. Entretanto, as lutas e resistências persistem. Novos motivos e caminhos continuam sendo buscados, como indica um ativista do MXVPS:

Parece-me que de 2008 pra cá, temos duas questões: uma é o próprio processo de cooptação junto aos povos locais, indígenas, pescadores, ribeirinhos, agricultores, que se intensifica e, ao se intensificar, ele provoca baixas no movimento, mas ao mesmo tempo [...] vem um avanço na reflexão do que é esse projeto de Belo Monte nesse último modelo e do que nós podemos apresentar como uma outra forma de ver o mundo, de ver a vida, de ver as relações sociais e econômicas. Então, eu acho que a pauta avança no sentido de que novos elementos vão se inserindo nesse debate e vão trazendo a percepção de que outros modelos de energia são possíveis na Amazônia em relação aos hidrelé-

49. Idem.

50. Entrevista concedida a Sérgio Corrêa em junho de 2012. 
tricos, com resultados de equilíbrio nas relações, coisa que esse modelo não apresentou. Tem uma pauta e uma agenda que se amplia muito mais ${ }^{51}$.

Em Carta endereçada à presidenta Dilma, em fevereiro de 2011, o MXVPS, o $\mathrm{MAB}$ e vários outros movimentos, sob a denominação de Aliança em Defesa dos Rios da Amazônia, denunciam:

0 peso descomunal nesses planos para a construção de novas hidrelétricas na região amazônica reflete, entre outras coisas, o fato de que o planejamento do setor elétrico é realizado sem participação democrática [...] Alem disso, reflete a proximidade ou, como dizem alguns, "relações promíscuas" entre o setor elétrico do governo (MME/EPE/Eletrobrás), comandado atualmente pelo grupo Sarney e grandes empreiteiras, como Odebrecht, Camargo Correia, Andrade Gutierrez [...] 0 resultado desse quadro político-institucional é que decisões no planejamento do setor elétrico são tipicamente orientados mais por uma lógica privada do que critérios de eficiência econômica, justiça social e sustentabilidade ambiental, ou seja, interesses públicos estratégicos, consagrados no arcabouço legal a partir da Constituição Federal de $1988^{51}$.
Em junho de 2012, ocorreu o Encontro dos Povos da Amazônia: Xingu + 23, na Comunidade Santo Antônio, município de Vitória do Xingu, a qual foi desapropriada para a construção de Belo Monte. 0 Encontro visou protestar contra a desapropriação, retomar a memória da resistência contra Belo Monte e reconstruir a unidade do movimento, além de se posicionar criticamente frente à Conferência Rio+20, que ocorria nesse período ${ }^{53}$. Do local do encontro os participantes seguiram para uma área onde o rio havia sofrido intervenções de barramento, quando em ato simbólico cavaram um sulco recompondo o seu curso normal e plantaram algumas mudas, simbolizando o reflorestamento da área desmatada pelo empreendimento. Em Altamira, nesse mesmo dia, uma outra manifestação reuniu um conjunto diverso de movimentos e organizações para protestar em frente à sede da Norte Energia, sendo observada por forte aparato militar. No dia seguinte, houve a ocupação do escritório do Consorcio Construtor Belo Monte - CCBM, ocorrendo destruição de máquinas e de documentos, em protesto pelo não cumprimento das condicionantes e pela violação de direitos. Esse fato teve repercussão negativa nacional e internacional. $\mathrm{Na}$ Declaração Final do Xingu + 23, o MXVPS reafirma sua disposição de continuar lutando: “após 23 anos de resistência contra o bar-

51. Entrevista concedida a Sérgio Corrêa em março de 2012.

52. Essa Carta foi fruto de uma intensa e ampla mobilização na sociedade brasileira protagonizada pelo MXVPS e seus parceiros, que gerou um abaixo assinado (http://www.internationalrivers.org/pt-br/resources/ carta-a-alian\%C3\%A7a-em-defesa-dos-rios-amaz\%C3\%B4nicos-o-presidente-dilma-3076). Além dessa mobilização, ocorreram outras mobilizações nacionais contra Belo Monte, que geraram, entre outras iniciativas, a articulação de abaixo-assinado ("Petição Pública: Abaixo assinado contra Belo Monte": http://www. peticaopublica.com.br/pview.aspx?pi=p2012n19449) e a divulgação de um vídeo produzido pelo Movimento Gota D'Água, com a participação de artistas, acompanhada de petição pública (“Gota d'Água+10”: http:// www.ecodesenvolvimento.org/posts/2011/novembro/movimento-gota-dagua-convoca-artistas-para; http://www.peticaopublica.com.br/pview.aspx?pi=P2011N16979). Acesso em 20 jun. 2013.

53. Como a Conferência Rio + 20, o encontro ganhou a denominação de Xingu + 23 (uma alusão aos 23 anos do histórico encontro dos povos indígenas do Xingu). 
ramento do Xingu, não haverá esmorecimento nem trégua na luta pela vida do rio e pelos direitos de seus povos" ${ }^{24}$.

Novas ocupações dos canteiros de obra de Belo Monte continuaram ocorrendo. Em maio de 2013, indígenas dos rios Xingu, Tapajós e Teles Pires, além de pescadores e ribeirinhos da Volta Grande do Xingu, sob a liderança dos índios Munduruku, ocuparam o canteiro principal da obra do AHE Belo Monte, no município de Vitória do Xingu, a $50 \mathrm{~km}$ de Altamira. Exigiam a regulamentação da consulta prévia e a suspensão imediata das obras e dos estudos relacionados aos empreendimentos hidrelétricos nos rios onde vivem ${ }^{55}$. Em resposta, chegaram ao local contingentes da Força Nacional, Polícia Militar e Polícia Civil, a fim de cumprir mandado judicial de reintegração de posse contra "brancos" presentes na ocupação. Os manifestantes, em carta, mencionaram os trabalhadores dos canteiros de obras como possíveis aliados: "os trabalhadores que vivem nos alojamentos nos apoiam e deram dezenas de depoimentos sobre problemas que vivem aqui. São solidários à nossa causa. Eles nos entendem. Tanto eles quanto nós estamos em paz" ${ }^{56}$. Com a carta Todo
Apoio à Ocupação Indígena nos Canteiros de Belo Monte, um conjunto amplo de movimentos sociais e entidades da sociedade civil nacionais e estrangeiras assim se pronunciou: "estamos em um momento muito importante da luta contra o projeto do governo brasileiro para a Amazônia, proposta desenvolvimentista atrasada e autoritária que exaure as riquezas naturais da região e destrói o planeta, tendo a usina de Belo Monte e as demais barragens como carro chefe deste processo" 57 . Em seguida o Tribunal Regional Federal de Brasília deferiu a reintegração de posse do canteiro de obras, autorizando o uso da força policial. No entanto, a pedido do MPF, o Tribunal concedeu 24 horas para os manifestantes se retirarem do local. Mais uma vez ocorria uma batalha na esfera judicial associada à luta na esfera da ação coletiva, tendo como parceiro o MPF.

Menos de um mês depois, indígenas Xypaia, Arara, Kayapó, Munduruku e Tupinambá voltaram a ocupar o mesmo canteiro, exigindo que as obras de Belo Monte e os estudos para a construção de usinas no Rio Tapajós fossem suspensos até serem realizadas as consultas aos povos indígenas. Novamente um gesto de aproximação com os trabalhadores da construção civil ${ }^{58}$ :

54. Ver http://www.xinguvivo.org.br/2012/06/17/declaracao-final-do-xingu-23/ . Acesso em 17 jun. 2013. 55. https://ocupacaobelomonte.wordpress.com/2013/05/27/carta-no-7-governo-federal-nos-voltamos/. Acesso em 19 jun. 2013.

56. http://www.brasildefato.com.br/node/12817. Acesso em 15 jun. 2013.

57. http://www.diarioliberdade.org/brasil/batalha-de-ideias/38214-organiza\%C3\%A7\%C3\%B5es-e-movimentos-sociais-nota-de-apoio-\%C3\%A0-ocupa\%C3\%A7\%C3\%A3o-ind\%C3\%ADgena-nos-canteiros-de -belo-monte.html. Acesso em 15 jun. 2013.

58. Em entrevista concedida a Sérgio Corrêa, em maio de 2013, um trabalhador deste canteiro, assim avaliou as condições de trabalho e a ação do Sindicato: "hoje, o sindicato que existe lá, o SINTAPAVE [Sindicato dos Trabalhadores da Construção Civil Pesada], é da empresa, eles mesmos [a empresa] trouxe esse sindicato, veio com a empresa, não foi os trabalhadores que trouxe, o sindicato é deles! Não é do trabalhador! Os sindicatos que tavam lutando por nós não deixaram, foram demitidos [...] E, assim, eles sempre compram trabalhadores, lideranças! Isso é muito forte [...] As conquistas não têm aparecido, a gente corre atrás, mas não tem conseguido". Para uma análise das lutas dos "peões" das obras do PAC, com foco na construção das hidroelétricas de Jirau e Santo Antonio, em Rondônia, ver Véras de Oliveira (2014) e com foco em Suape, em Pernambuco, ver Veras de Oliveira (2013). 
Nós, indígenas, escrevemos a vocês trabalhadores da obra da barragem. 0 CCBM está dizendo para o governo e imprensa que nós somos inimigos, nós índios e vocês trabalhadores de Belo Monte [...]. Nós sabemos dos problemas que vocês têm, porque durante a ocupação, vários trabalhadores vieram reclamar dos problemas que vocês passam na obra. Por isso, nós dizemos: queremos apoiar a causa de vocês. Queremos juntar as nossas reivindicações com as reivindicações dos trabalhadores [...] Nós, indígenas, vocês trabalhadores e os moradores da cidade - estamos todos sofrendo por conta dos mesmos culpados. Na hora em que nos juntarmos, eles vão ter que nos ouvir ${ }^{59}$.

Após tensas negociações, os manifestantes aceitaram ir a Brasília para conversar com o Governo Federal, mas garantindo que 140 dos 150 manifestantes fossem recebidos. Em carta, os manifestantes declararam que a ida a Brasília não representava um "acordo" ou uma "negociação": "nós não viemos negociar com vocês, porque não se negocia nem território nem vida. Nós somos contra a construção de barragens que matam a terra indígena, porque elas matam a cultura quando matam o peixe e afogam a terra. E isso mata a gente sem precisar de arma" ${ }^{60}$.

Diante da permanência do quadro que se impôs às populações atingidas pelo empreendimento Belo Monte e demais projetos hidroelétricos em implementação na Amazônia, os movimentos de re- sistência persistiram: "Nós vamos continuar essa luta, porque somos impactados por essas obras e temos de lutar pelos nossos direitos, para mostrar para a sociedade que nem tudo acontece como o governo diz, quando fala que os direitos indígenas estão sendo respeitados, e para fazer ver que e as comunidades não estão sendo bem atendidas" 61 .

Nessa resistência, foi possível constatar que a sua agenda é conflitante com aquela que se esgota na compensação. Há indicativos de que os povos indígenas envolvidos nesses movimentos contestatórios, não estão dispostos a "negociar" com as empresas as condicionantes e compensações dos empreendimentos. A sua agenda é de defesa de seus territórios, de suas tradições e costumes, da preservação dos recursos naturais, uma vez que estes são entendidos como fundamentais para sua produção e reprodução social material e simbólicocultural. Nesse sentido, o que se apresenta é uma evidente contestação, por um lado, a um modelo de desenvolvimento e de sociedade, encarnados nos grandes projetos hidrelétricos, marcados pela violência institucional (militarização) e simbólica; e, por outro, a defesa de outras lógicas e racionalidades de organização e existência social e convivência com a natureza. Essa posição provoca um deslocamento do campo de conflitos das compensações ou condicionantes para um campo de disputas pela garantia e afırmação dos direitos, pelo controle, uso e sentido do território, como

59. https://ocupacaobelomonte.wordpress.com/2013/05/27/carta-aos-trabalhadores-do-ccbm/. Acesso em 22 jun. 2013.

60. http://www.cimi.org.br/site/pt-br/?system=newsCtaction=readttid=6943. Acesso em 23 jun. 2013.

61. Entrevista com Valdenir Munduruku, liderança indigena da Aldeia Teles Pires. Ver http://www.ihu. unisinos.br/entrevistas/520007-o-governo-brasileiro-nao-tem-interesse-em-respeitar-os-direitos-indigenas-entrevista-especial-com-valdenir-munduruku. Acesso em 09 jun. 2013. 
terreno de produção e reprodução da existência social e preservação ambiental ${ }^{62}$.

Foi assim que os protestos sobre Belo Monte continuaram em 2014, denunciando o não cumprimento das condicionantes presentes no Plano Básico Ambiental.

\section{Considerações finais}

Com um foco no processo histórico de implementação de uma intervenção de grande porte, estatal-privada, na bacia do rio Xingu, na forma do projeto AHE Belo Monte, e nas lutas e resistências em seu entorno, conduzidas por povos indígenas, movimentos populares e aliados, detemonos sobre como a emergência de uma nova agenda de desenvolvimento no Brasil, a partir do PAC, nos Governos Lula e Dilma, repercutiu em tal processo, sobre como o influenciou. Vendo por outro ângulo, buscamos participar do debate sobre esse momento de retomada de políticas desenvolvimentistas, observando-o pelo prisma dos conflitos sociais gerados em torno da implementação de um dos mais expressivos projetos do PAC. Procuramos valorizar, com isso, a constituição e ação dos atores, as condições sociais e institucionais de seus posicionamentos, os conflitos, composições e arranjos daí resultantes.

No debate recente sobre o tema geral do desenvolvimento - o que, por sua vez, como aqui vimos, perpassa o processo de construção social do empreendimento AHE Belo Monte - apuramos que são sinalizadas racionalidades diversas, enquanto modos de conceber e argumentar sobre o tema. Tomamos essas racionalidades como um aspecto importante na disputa pela legitimidade social, na mobilização e constituição dos atores, no balizamento de seus posicionamentos, na produção dos conflitos e composições. $\mathrm{Na}$ forma de tipos ideais, podemos destacar:

- Sob a primazia de noções como eficiência, produtividade, competitividade, identifica-se desenvolvimento com crescimento e se estrutura o argumento em torno das virtudes do Mercado, em contraste com as ineficiências do Estado, e da prioridade das políticas econômicas frente às sociais. Têm grande apelo nos ambientes identificados com o ideário neoliberal. Destacam-se aqui, como seus principais suportes sociais, agentes empresariais, economistas do mainstream, tecnocratas, grande mídia etc., que

62. Nos termos de Boaventura de Sousa Santos, poderíamos observar aqui fundamentos de um campo contra-hegemônico. Essa foi uma possibilidade amplamente discutida em Correa (2014). Santos se apropria das categorias de hegemonia e contra-hegemonia de Antonio Gramsci, problematizando-as e reelaborando-as com vistas a analisar a sociedade contemporânea, submetida a processos de globalização hegemônicos e contra-hegemônicos, demarcando seus limites e possibilidades. Apoia-se na emergência de experiências e perspectivas sociais, historicamente excluídas e ocultadas pela Razão Indolente, especialmente relacionadas a formas de resistências aos processos de dominação coloniais nas periferias e semiperiferias do mundo (SANTOS et al., 2005; SANTOS, 2006). Ao ajudar a trazer à tona novas e plurais experiências e perspectivas sociais, por meio da Sociologia das ausências e da Sociologia das emergências, Santos possibilita tanto identificar e visibilizar novos atores sociais, com suas demandas e jeitos de ser, existir e fazer política, quanto complexificar o campo de análise das formas de opressão e dominação e das lutas sociais, tomando-as para além de uma polarização clássica capital versus trabalho (SANTOS, 2003). Assim repõe o debate sobre os processos de construção de hegemonia e contra-hegemonia. Para ele, não existe uma condução única, mas plural do processo de construção contra-hegemônica e de emancipação social. 
buscam dotar aquelas noções como suficientes para a defesa dos grandes projetos, mas diante das resistências apresentadas precisam justificá-los lançando mão de outros argumentos, social e ambientalmente inspirados.

- Sob a projeção dos discursos do combate à pobreza, da distribuição de renda e da diminuição das desigualdades, ganha relevância os princípios da equidade, igualdade, distribuição. 0 argumento se estrutura em termos da necessidade do Estado assumir um duplo papel de indutor do crescimento econômico e promotor do desenvolvimento social, buscando compatibilizar equidade e eficiência. 0 Estado e o Governo são posicionados entre a Sociedade e o Mercado. Esse é um lugar que tem se mostrado em constante exercício, com suas tensões e ambivalências, nos Governos Lula e Dilma.

- Sob a referência do respeito ao meio ambiente, nas últimas décadas e em todo o mundo, emergiu o princípio da sustentabilidade. 0 argumento se articula em favor da preservação ambiental, do equilíbrio ecológico e, sob esse critério, da reorientação das estratégias de investimentos públicos e privados. Ganha peso nesse tema os agentes sociais não governamentais e não empresariais (especialmente, ONGs e ativistas ambientalistas). Na Amazônia, em particular, têm se formado configurações prático-discursivas envolvendo povos indígenas e comunidades rurais, fazendo interagir sustentabilidade ambiental e social. Grosso modo, as disputas se estabelecem entre: em uma mão, os compromissos em favor do meio ambiente arrancados, por parte dos segmentos em defesa da sustentabilidade ambiental, junto aos agentes governamentais e empresariais; e, na outra, as atitudes adotadas, por parte destes, entre compromissos reais e estratégias de pura justificação.

- Sob processos históricos de constituição de formas de organização popular e de pressão, por parte destas, em relação aos agentes econômicos e políticos estratégicos (empresas e Estado), colocamse em evidência os propósitos da participação e controle sociais. 0 argumento se estrutura em torno dos direitos de cidadania (sociais e políticos) - agenda reivindicativa - e da ressignificação da ideia de desenvolvimento - agenda propositiva. Ganham peso, por esse ângulo, o lugar e as possibilidades dos movimentos populares e sindicais, frente ao Mercado e ao Estado, enquanto capazes de constituir um contraponto, a partir das perspectivas social e ambiental (redistributiva, sustentável e participativa), à primazia das referências da eficiência, produtividade e competitividade, em geral associadas às de ordem e segurança.

$\mathrm{Na}$ análise que aqui nos propusemos a realizar, sobre a dinâmica sócio-histórica constituída em torno do empreendimento AHE Belo Monte, pudemos notar que tais racionalidades, ao mesmo tempo em que informam a distinção de campos e fases do processo analisado (por exemplo, com a associação entre a emergência do protagonismo indígena na luta contra o referido projeto e o momento de "ambientalização dos conflitos” na Amazônia), não se apresentam sempre de modo tão claramente distintas (por exemplo, como se colocam para os Governos Lula e Dilma, nas suas diferenças e divergências internas e nos seus diferentes momentos, as referências da eficiência, da defesa da ordem, da sustentabilidade ambiental, da distribuição de ren- 
da, do combate à pobreza, da participação cidadã, da democratização da sociedade?).

Particularmente no que concerne aos grandes projetos - como os que vêm sendo implementados com o PAC, a exemplo do AHE Belo Monte - ganha destaque, como um aspecto de sua viabilização, a constituição de complexos arranjos institucionais (conforme abordado em GOMIDE; PIRES, 2014), os quais articulam agentes públicos e privados, internacionais, nacionais e, com menor peso, locais, das áreas técnica, burocrática, financeira e produtiva, excluindo em sentido mais substantivo os agentes sociais e estatais mais centralmente referidos às demandas por equidade, sustentabilidade e participação. É o que dá ensejo aos conflitos sociais, trabalhistas e ambientais que os vêm marcando. No entanto, os territórios nos quais incidem tais intervenções, encontram-se povoados por outros agentes institucionais, os quais mesmo estando fora daqueles arranjos podem constituir ações mais ou menos diretamente orientadas para a disputa frente a tais empreendimentos. São exemplos: sindicatos, organizações religiosas, ONGs, Ministério Público, instituições públicas (econômicas, ambientais, trabalhistas, sociais), movimentos sociais (indígenas, barragens, ribeirinhos, comunidades tradicionais). Ou seja, além dos arranjos especialmente constituídos para propiciar condições de governança, legalidade e legitimidade ao empreendimento $^{63}$, tais territórios contam com formas institucionais diversas, mais ou menos estabelecidas e consolidadas, mais ou menos conectadas com configurações institucionais nacionais e internacionais, as quais dão suporte à organização e formas de luta e resistências populares.
Isso possibilita a resistência, mas também pavimenta os processos de justificação, ao se colocar sob assimetrias de poder abissais. No tocante a isso, Zhouri e Oliveira (2007, p. 121) destacam:

\begin{abstract}
0 resultado dessa dinâmica [imposta com os grandes empreendimentos] é a intensificação do uso de áreas economicamente marginais e a expansão da fronteira econômica do mercado sob territórios historicamente ocupados por agricultores familiares e minorias étnicas. Nessa medida, o que se tem é a conformação de zonas de conflito onde as assimetrias de poder que atravessam as relações entre os segmentos em disputa resvalam em processos violentos de expropriação das populações locais.
\end{abstract}

Este artigo pretendeu evidenciar que, do ponto de vista sociológico, na análise de processos sócio-históricos como o aqui tratado, o mais importante é atentar para a centralidade dos conflitos sociais, discutindo em que medida as lutas e resistências populares logram ir além do campo de possibilidades da justificação nos projetos dominantes de desenvolvimento e da dinâmica de acumulação de capital que os movem. Quanto a isso, alinhamo-nos com Ramalho, Santos e Lima (2013, p. 176) quando, ao mesmo tempo em que reconhecem tamanha assimetria de poderes em tais situações, não deixam de admitir "a capacidade de agencia de determinados grupos sociais (principalmente sindicatos de trabalhadores, associações de moradores, organizações ambientalistas, igreja, entre outros), para mudar relações de poder e para regular o comportamento empresarial". No espírito de Boltanski e Chiapello (2009, p. 527), es- 
peramos ter contribuído para a reativação da crítica e para a reabertura dos caminhos pelos quais ela é capaz de enveredar, não só mostrando que sua ação é real, mas também tentando apresentar um panorama dos deslocamentos do capitalismo que seja capaz de servir de base à recomposição das forças críticas, a fim de desmentir os discursos fatalistas nos quais não há motivo para se deixar de acreditar caso nada mude.

\section{Referências}

ALMEIDA, A. A reconfiguração das agroestratégias: novo capítulo da guerra ecológica. In: ALMEIDA, A; SAUER, S. (Orgs.). Terras e territórios na Amazônia: demandas, desafios e perspectivas. Brasília: Editora Universidade de Brasília, 2011.

BARAÚNA, G.; MARIN, R.. 0 "fator participativo" nas audiências públicas das hidrelétricas de Jirau, Santo Antônio e Belo Monte. In: ZHOURI, A. (Org.). As tensões do lugar: hidrelétricas, sujeitos e licenciamento ambiental. Belo Horizonte: Ed. UFMG, 2011.

BERMANN, C. 0 projeto da usina hidrelétrica Belo Monte: a autocracia energética como paradigma. Novos Cadernos NAEA. v. 15, $\mathrm{n}^{\circ} 1$, p. 5-23, jun. 2012a.

BOITO JR, A. A economia capitalista está em crise e as contradições tendem a se aguçar. Abril de 2012. Disponivel em:

$<$ http://www.brasildefato.com.br/content $/ \%$ E2\%80\%9C-economia-capitalista-est $\% \mathrm{C} 3 \% \mathrm{~A} 1$-em-crise-e-contradi $\%$ C $3 \%$ A 7 \% C $3 \%$ B 5 es - tendem-se-agu \% C3\%A7ar\%E2\%80\%9D>. Acesso em: 14 mai. 2014.

BOLTANSKI, L; CHIAPELLO, E. 0 novo espírito do capitalismo. São Paulo: Martins Fontes, 2009.

BOSCHI, R. Introdução: instituições, trajetórias e desenvolvimento: uma discussão a partir da
América Latina. In: BOSCHI, R. (org.). Variedades de capitalismo, política e desenvolvimento na América Latina. Belo Horizonte: Ed. UFMG, 2011.

BRASIL. Programa de Aceleração do Crescimento: balanço 4 anos (2007-2010). Brasília: Ministério do Planejamento, 2010.

PAC 2. Brasília: Ministério do Planejamento, 2012.

BRESSER-PEREIRA, L, Desenvolvimento e subdesenvolvimento no Brasil. In: BOTELHO, André; SCHWARCZ, Lilia (Orgs). Agenda brasileira: temas de uma sociedade em mudança. São Paulo: Companhia das Letras, 2011.

. 0 novo desenvolvimentismo e a ortodoxia convencional. São Paulo em Perspectiva. São Paulo: SEADE. v. 20, nº 3, p. 5-24, jul./set. 2006.

. Retomada da revolução nacional e novo desenvolvimentismo. In: BRESSER-PEREIRA, L. Desenvolvimento e crise no Brasil: história, economia e política de Getúlio Vargas a Lula. 5 ed. rev. São Paulo: Editora 34, 2003.

CAMARGO, A.; CAPOBIANCO, J.P.; OLIVEIRA, J. A. P. (Coord.). Meio ambiente no Brasil: avanços e obstáculos pós-Rio-1992. São Paulo: Editora Estação Liberdade (2002).

CAMPGNOLO, M. G. M. B. A Tragédia dos Comuns às Avessas: hidrelétricas do Xingu e a expansão da fronteira energética. Texto apresentado no $31^{\circ}$ Encontro Anual da ANPOCS (22 a 26 de outubro de 2007), Caxambu- MG.

CARNEIRO, R. Um intelectual em seu labirinto. Carta Maior, 03/04/2012. Disponível em: http:// www.cartamaior.com.br/templates/materiaMostrar.cfm?materia_id=19890. Acesso em: 15 mai. 2012.

CASTRO, E. (Introdução). Amazônia: sociedade, fronteiras e políticas. Dossiê Amazônia. Caderno CRH, v. 25, $n^{\circ}$ 64, Salvador: Ed. UFBA, jan./ abr. 2012.

CEPÊDA, V. Inclusão, democracia e novo desenvolvimentismo: um balanço histórico. Revista 
de Estudos Avançados IEA- USP, $n^{\circ}$ 75. São Paulo: USP, 2012.

COELHO, M. et al. Questão energética na Amazônia: disputa em torno de um novo padrão de desenvolvimento econômico e social. BelémPA. Novos Cadernos NAEA. v. $13, n^{\circ} 2$, p. 83102, dez. 2010.

CORRÊA, S. Educação Popular do campo e desenvolvimento territorial na Amazônia: uma leitura a partir da Pedagógica do Movimento dos Atingidos por Barragem (MAB). João Pessoa: Dissertação de Mestrado, UFPB. 2007.

As lutas e resistências do Movimento Xingu Vivo para Sempre diante do projeto hidrelétrico Belo Monte: o padrão de desenvolvimento da Amazônia em disputa. Tese de Doutorado. Campina Grande: PPGCS, 2014.

DIEGUES, A. Modelo econômico e os modos de vida: confrontos e alternativas no Sul do Pará. In: DIEGUES, A. (Org). Desmatamento e modos de vida na Amazônia. São Paulo: NUPAUB, 1999.

DINIZ, E. 0 contexto internacional e a retomada do debate sobre desenvolvimento no Brasil contemporâneo (2000/2010). Dados. Rio de Janeiro, v. $54, \mathrm{n}^{\circ} 4,2011$.

DRAIBE, S; RIESCO, M. Estados de Bem-Estar Social e estratégias de desenvolvimento na América Latina; um novo desenvolvimentismo em gestação? Sociologias. Porto Alegre, v. 13, $\mathrm{n}^{0}$ 27, maio/ago, 2011, p. 220-254.

EPE/MME. Plano Nacional de Energia - PNE 2030. Informe à Imprensa. Rio de Janeiro, 26 de janeiro de 2007. Disponivel em: <http://www. epe.gov.br/PNE/20070626_2.pdf>. Acesso em: 15 mai. 2014.

Projeto da Usina Hidrelétrica de Belo Monte. Fatos e dados. fev/ 2011. Disponivel em: <http://www.epe.gov.br/leiloes/Documents/ Leil\%C3\%A3o\%20Belo\%20Monte/ Belo\%20 Monte \%20-\%20Fatos\%20e\%20Dados\%20-\%20 POR.pdf>. Acesso em: 20 mai. 2014.
FEARNSIDE, F. (Entrevista). A usina hidrelétrica de Belo Monte em pauta. Política Ambiental/ Conservação Internacional - $\mathrm{n}^{0} 7$, jan./2011. Belo Horizonte, 2011. Disponivel em: <http:// www.conservacao.org/publicacoes/files/politicaambiental7.pdf>. Acesso em: 16 mai. 2014.

FEARNSIDE, F.; MILLIKAN, B. (Orgs). 0 setor elétrico brasileiro e a sustentabilidade no século XXI: oportunidades e desafios - fonte de energia limpa. Brasília: Rios Internacionais. Brasil, 2012.

FIORI, José L. 0 "desenvolvimentismo de esquerda”. Carta Maior, 2012a. Disponível em: <http://www.cartamaior.com.br/templates/ colunaMostrar.cfm?coluna_id=5495\&tboletim_ $\mathrm{id}=1140$ \&componente_id=18221 $>$. Acesso em: 3 mar. 2012.

Desenvolvimentismo e "dependência". Carta Maior, 2012b. Disponível em: <http:// www.cartamaior.com.br/templates/colunaMos-

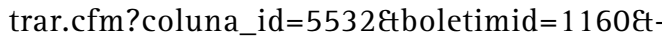
componente_id=18561>. Acesso em: 03 abr. 2012.

A miséria do "novo desenvolvimentismo”. Carta Maior, 2011. Disponivel em: <http:// www.cartamaior.com.br/templates/colunaImprimir.cfm?coluna_id=5334>. Acesso em: 30 nov. 2012.

FVPP. A história do movimento pelo desenvolvimento da Transamazônica e Xingu. Brasília: MMA, 2006. (Série Sistematização, VII).

GOMIDE, A.; PIRES, R.. Capacidades estatais e democracia: arranjos institucionais de políticas públicas. Brasília: IPEA, 2014.

HENCHEN, M.; MAGALHÃES, S. Ambientalização da ação pública no território Xingu: a estratégia dos mediadores camponeses. XV Encontro do CISO. 04-07/09/2012, UFPI. Disponível em: <http://www.sinteseeventos.com.br/ ciso/anaisxvciso/resumos/GT28-31.pdf>. Acesso em: 16 mai. 2014.

HERNÁNDEZ, F.; BERMANN, C. A usina de Belo Monte: energia e democracia em questão. Polí- 
tica Democrática. Brasília: Fundação Astrojildo Pereira, 2010.

HURWITZ, Z. et al. Mega-Projeto, Mega-Riscos. São Paulo: Amigos da Terra/Amazônia Brasileira/International Rivers, 2011.

IVO, A. O paradigma do desenvolvimento: do mito fundador ao novo desenvolvimento. Caderno CRH, v. 25, $\mathrm{n}^{\circ}$ 65, Salvador, mai/ago. 2012.

IVO et al. (Coord.). Dicionário Temático - Desenvolvimento e a Questão Social: 81 problemáticas contemporâneas. São Paulo: Annablume, 2013.

KERSTENETZKY, C. L. Welfare State e Desenvolvimento. DADOS. Rio de Janeiro, v. 54, $\mathrm{n}^{\circ} 1$, 2011, p. 129-156.

MOTTA, L.E. Judicialização da política e representação funcional no Brasil contemporâneo: uma ameaça à soberania popular? Confluências, v.12, $\mathrm{n}^{\circ}$ 1. Niterói: PPGSD-UFF, p. 192218 , out/2012.

LEITÃO, K. A dimensão territorial do Programa de Aceleração do Crescimento: um estudo a partir do PAC no Pará e o lugar que ele reserva à Amazônia no desenvolvimento do país. Tese (Doutorado em Planejamento Urbano e Regional). São Paulo: FAU-USP, 2009.

LOPES, J. S. L. Sobre processos de "ambientalização" dos conflitos e sobre dilemas da participação. Horizontes Antropológicos, v.12, $\mathrm{n}^{0}$ 25 Porto Alegre jan/jun, 2006.

MAB. MAB - uma história de luta, desafios e conquistas. São Paulo: MAB, 2002.

MAGALHÃES, S.; HERNÁNDEZ, F. Ciência, cientistas, democracia desfigurada e licenciamento ambiental sob constrangimento. In: ZHOURI, A. (Org.). As tensões do lugar: hidrelétricas, sujeitos e licenciamento ambiental. Belo Horizonte: Ed. UFMG, 2011.

MAGAlHÃES, S.; HERNÁNDEZ, F. Painel de Especialistas: análise critica do estudo de im- pacto ambiental do aproveitamento hidrelétrico de Belo Monte. 29 set. 2009

MELO, A. 0 assédio da Eletronorte sobre o povo e as entidades na região de Altamira. In: SEVÁ FILHO, 0. (Org.). Tenotã-Mõ: Alertas sobre as consequências dos projetos hidrelétricos no rio Xingu. São Paulo: International Rivers Network, 2005.

MONTEIRO, T. Belo Monte é a forma de viabilizar definitivamente a mineração em terras indígenas (11/09/2012). Disponível em: <http:// www.correiocidadania.com.br/index.php?catid $=34 \% 3$ Amanchetectid=7608\%3Amanchete1 10912Ctoption=com_contentEtview=article $>$. Acesso em: 17 jun. 2014.

PÊGO, B.; CAMPOS NETO, C. O PAC e o setor elétrico: desafios para o abastecimento do mercado brasileiro (2007-2010). Texto para Discussão, $n^{\circ}$ 1329. Brasília: Ipea, 2008.

POCHMANN, M. Novo desenvolvimentismo como resposta à crise global. In: CASTRO, D.; MELO, J. (Orgs.), Panorama da comunicação e das telecomunicações no Brasil, 2011- 2012: Indicadores. Brasília: Ipea, 2012.

PONTES JR, F. Belo Monte e o último ritual indígena. 19/04/2011. Disponivel em: http:// www.xinguvivo.org.br/2010/10/14/historico/. Acesso em: 15 mai. 2014.

PONTES JR, F.; BELTRÃO, J. Xingu, barragens e nações indígenas. In: SEVÁ FILHO, O. (Org.). Tenotã-Mõ: Alertas sobre as consequências dos projetos hidrelétricos no rio Xingu. São Paulo: International Rivers Network, 2005.

PORTO-GONÇAVES, C. Amazônia, Amazônias. 2.ed. São Paulo: Contexto, 2005.

RAMALHO, J. R.; SANTOS, R. S. P.; LIMA, R. J.C. Estratégias de desenvolvimento industrial e dinâmicas territoriais de contestação social e confronto político. Sociologia \&t Antropologia. Rio De Janeiro, v. 03.05, jun/2013, p. 175-200.

RIDENTI, M. Desenvolvimentismo: o retorno. Revista Espaço Acadêmico, $\mathrm{n}^{\circ}$ 92, janeiro de 
2009. Disponível em: <http://www.espacoacademico.com.br/092/92ridenti.pdf>. Acesso em: 16 mai. 2014.

SARDAN, J. P. 0. Anthropology and development: understand contemporary social change. London \& New York: Zed Books, 2005.

SANTOS, B. Dilemas do nosso tempo: globalização, multiculturalismo e conhecimento. Currículo sem Fronteiras, v.3, ${ }^{\circ}$ 2, jul/dez, 2003c. p.5-23.

A gramática do tempo: para uma nova cultura política. São Paulo: Cortez, 2006.

SANTOS, B. et al. (Introdução): Para ampliar o cânone da ciência: a diversidade epistemológica do mundo. In: Semear outras soluções: os caminhos da biodiversidade e dos conhecimentos rivais. Rio de Janeiro: Civilização Brasileira, 2005b.

SEN, A. Choice, Welfare, and Measurement. Cambridge. Massachusetts: Harvard University Press, 1999.

SEVÁ FILHO, O. Belo Monte de mentiras: trinta anos de manobras estranhas, omissão de informações cruciais e algumas mentiras grossas. Disponivel em: http://xa.yimg.com/kq/ groups/17072343/295162363/name/BELO+MONTE+de+mentiras.docx. Acesso em: 03 mai. 2014.

. Povos indigenas, as cidades e os beiradeiros do rio Xingu que a empresa de eletricidade insiste em barrar. In: SEVÁ FILHO, O. (Org.). Tenotã-Mõ: Alertas sobre as consequências dos projetos hidrelétricos no rio Xingu. São Paulo: IRN, 2005.

SICSÚ, J.; PAULA, L. F.; MICHELET, R. Por que novo-desenvolvimentismo? Revista de Economia Política. v. 4, $\mathrm{n}^{\circ}$ 27, 2007.

SOUZA, A.; FILIPPI, E. O Programa Amazônia Sustentável: novas e velhas estratégias de inserção Continental. Amazônia. Belém, v. 6, $\mathrm{n}^{\circ}$ 11, jul/dez, 2010.

SWITKES, G.; SEVÁ FILHO, O. (Resumo Executivo). In: SEVÁ FILHO, O. (Org.). Tenotã-Mõ:
Alertas sobre as consequências dos projetos hidrelétricos no rio Xingu. São Paulo: IRN, 2005.

Belo Monte não sairia do papel sem governo. Entrevista publicada em 27/07/2010. Reuters/Brasil Online. Disponível em: <http:// oglobo.globo.com/economia/mat/2010/07/27/ tolmasquim-belo-monte-nao-sairia-do-papelsem-governo-917252267.asp>. Acesso em: 13 mai. 2014.

VÉRAS DE OLIVEIRA, R. Suape em construção, peões em luta: o novo desenvolvimento e os conflitos do trabalho. Caderno CRH, Salvador, v. 26, nº 68, mai/ago, 2013.

Brasil em obras, peões em luta, sindicatos surpreendidos. Revista Crítica de Ciências Sociais, 103, mai. 2014.

VIANNA, L. A modernização brasileira e a política burguesa cinzenta. Entrevista Especial. Unisinos, maio de 2012. Disponivel em: <http:// www.ihu.unisinos.br/entrevistas/509424-entrevista-especial-com-luiz-werneck-vianna>. Acesso em: 13 jul. 2012.

ZHOURI, A.; OLIVEIRA, R. Desenvolvimento, conflitos sociais e violência no Brasil rural: o caso das usinas hidrelétricas. Ambiente \&t Sociedade. Campinas, v. 10, $\mathrm{n}^{\circ}$ 2. jul/dez, 2007. 
RESUMO

Este artigo trata da emergência de uma nova agenda de desenvolvimento no Brasil, pela ótica dos conflitos sociais. Mais especificamente, versa sobre o processo de construção do Aproveitamento Hidrelétrico de Belo Monte - AHE Belo Monte, empreendimento situado no Rio Xingu, sudoeste do Pará. Parte do pressuposto de que o ângulo dos conflitos sociais, tomados em perspectiva histórica, pode trazer importante contribuição à análise do novo momento do desenvolvimento do País e da Amazônia. Pergunta-se se as lutas e resistências ao projeto AHE Belo Monte têm contribuído para redimensioná-lo, indo além de um ponto no qual, enquanto crítica social, venham a ser assimilados pela dinâmica de acumulação tão somente como justificação. Baseia-se em pesquisa qualitativa, tendo priorizado entrevistas semiestruturadas, observação direta e análise de documentos.

\section{PALAVRAS-CHAVE}

Novo desenvolvimento. Mega projetos Amazônia. Conflitos sociais.

\section{ABSTRACT}

This article deals with the emergence of a new development agenda in Brazil, from the perspective of social conflicts. More specifically, deals with the hydroelectric construction process of Belo Monte - AHE Belo Monte project, located on the Xingu River, southwest of Pará. It understands that the angle of social conflicts, taken in historical perspective, can bring important contribution to analysis of the new moment of development of the country and the Amazon. Ask yourself if the popular struggles and resistances have been able to resize this project, going beyond a point at which, as a social critique, may be assimilated by the dynamics of accumulation only as justification. It is based on qualitative research, having prioritized semi-structured interviews, direct observation and document analysis.

\section{KEYWORDS}

New Development. Mega Projects Amazônia. Social Conflicts. 